\title{
COMMITMENT TO INTERNATIONAL HUMAN RIGHTS TREATIES: THE ROLE OF ENFORCEMENT MECHANISMS
}

\author{
YVONNE M. DUTTON*
}

\begin{abstract}
States continue to abuse human rights and commit mass atrocities even though for the past several decades they have overwhelmingly ratified a host of international human rights treaties. This Article seeks to explain this phenomenon and suggests that where treaty enforcement mechanisms are too weak for states to view them as a credible threat to their sovereignty, even states with the worst practices will regularly and readily commit to treaties designed to promote better human rights practices. I empirically test my credible threat theory against the explanatory power of other extant theories about treaty commitment by examining the relationship between treaty enforcement mechanisms and likelihood of ratification across a broad range of treaties. I include in my analysis the treaty creating the International Criminal Court ("ICC") - a treaty which contains a strong enforcement mechanism in the form of an independent Prosecutor and the Court, which can punish violators.

The results of the statistical tests using data from 1966 to 2008 provide support for the credible threat theory. I find that a state's human rights ratings do not influence ratification of international human rights treaties with the weakest enforcement mechanisms, such as those that only require the state to self-report its compliance. However, states with poorer records are significantly less likely to commit to the ICC treaty. The implication is that where enforcement mechanisms are strong, states may take their commitment more seriously and join only if they intend to comply.

* Associate Professor of Law, Indiana University Robert H. McKinney School of Law. I thank the University of San Diego School of Law and the One Earth Future Foundation for providing financial support for this project. Support was also received from the Department of Political Science of the University of Colorado at Boulder.
\end{abstract}


If we structure treaties with stronger enforcement mechanisms, perhaps fewer states will ratify, but at least when they do, they may be held to that commitment.

\section{TABLE OF CONTENTS}

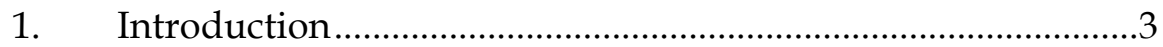

2. The International Human Rights Regime ..............................10

3. Existing Literature on State Commitment

to International Human Rights Treaties ...................................14

3.1. The Rationalist View ..............................................................15

3.1.1. Rationalist and Retrospective Calculations...................15

3.1.1.1. Domestic Practicce and Policy Compliance

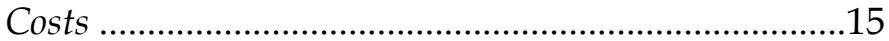

3.1.1.2. Costs of Domestic Ratification Processes..........18

3.1.2. Rationalist and Prospective Calculations......................19

3.1.2.1. Future Domestic Uncertainty Costs.................19

3.1.2.2. Future Hand-Tying Benefits ............................20

3.1.2.2.1. Credible Commitment .........................20

3.1.2.2.2. Democratic Lock-In .............................22

3.2. The External Pressures View ...................................................23

4. Compliance Costs and the Credible Threat

of Strong Enforcement Mechanisms .........................................24

4.1. The Credible Threat Theory ...................................................24

4.2. Categorizing Levels of Enforcement Mechanisms in International Human Rights Treaties ......................................27

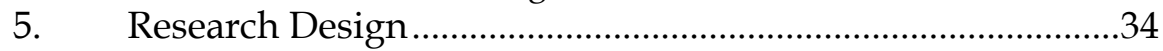

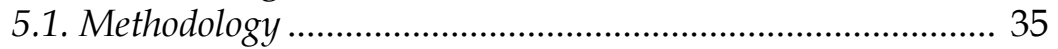

5.2. Dependent Variables................................................................36

5.3. The Main Explanatory Variable: Level of Human Rights

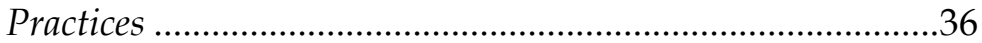

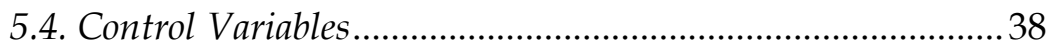

5.4.1. The Rationalist View ...................................................38

5.4.2. The External Pressure View ..........................................39

6. Empirical Analyses and Discussion of Results.......................40

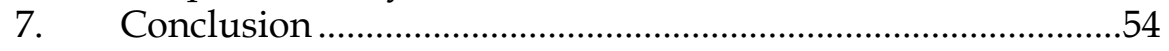

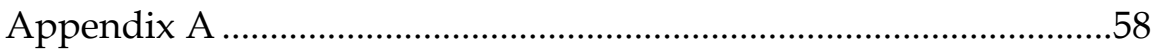

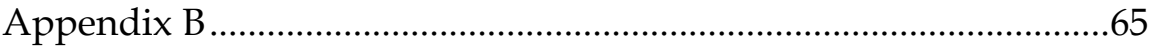




\section{INTRODUCTION}

Motivated by the destruction caused by World War II, the international community created a human rights regime designed to protect the basic human rights of all individuals. ${ }^{1}$ The international treaties at the foundation of this regime are the International Covenant on Civil and Political Rights ("ICCPR") and the International Covenant on Economic, Social and Cultural Rights ("ICESCR"), both of which were opened for signature and ratification in 1966 and came into force in 1976.2 Additional international human rights treaties followed, and the regime now boasts six primary treaties, to which the great majority of states belong. ${ }^{3}$ Table 1 below lists the six main international human rights treaties.

1 See Youcef Bouandel, Human Rights and Comparative Politics 1 (1997) (noting the increased focus on human rights following World War II); Thomas Buergenthal, The Normative and Institutional Evolution of International Human Rights, 19 HuM. RTS. Q. 703, 706 (1997) (observing that World War II influenced the United Nations' role in protecting individual's rights); James Raymond Vreeland, Political Institutions and Human Rights: Why Dictatorships Enter into the United Nations Convention Against Torture, 62 INT'L ORG. 65, 71 (2008) (noting the United Nations Convention Against Torture and Other Cruel, Inhuman or Degrading Treatment or Punishment as one of World War II's legacies).

2 See Buergenthal, supra note 1, at 705 (discussing the evolution of international human rights, with the first stage of the evolution lasting from the entry into force of the United Nations Charter through the 1966 adoption of International Covenants on Human Rights).

3 Treaty texts and information about their status is on file with the Secretary General of the United Nations at the United Nations Treaty Collection. See Multilateral Treaties Deposited with the Secretary-General: Chapter IV: Human Rights, United NAtions TReAty Collection [hereinafter U.N. Human Rights Treaties], http:/ / treaties.un.org/Pages/Treaties.aspx?id=4\&subid=A\&lang=en (last visited Nov. 18, 2012) (regarding the core human rights treaties). 
Table 1: The Six Main International Human Rights Treaties

\begin{tabular}{|l|l|l|l|}
\hline \multicolumn{1}{|c|}{ Treaty } & $\begin{array}{c}\text { Year } \\
\text { Open }\end{array}$ & \multicolumn{1}{|c|}{ Rights Protected } & Parties $^{4}$ \\
\hline $\begin{array}{l}\text { International Covenant } \\
\text { on Civil and Political } \\
\text { Rights (ICCPR) }\end{array}$ & 1966 & $\begin{array}{l}\text { Life, Liberty, Freedom } \\
\text { from Torture and } \\
\text { Slavery }\end{array}$ & 166 \\
\hline $\begin{array}{l}\text { International Covenant } \\
\text { on Economic, Social and } \\
\text { Cultural Rights (ICESCR) }\end{array}$ & 1966 & $\begin{array}{l}\text { Economic, Social, and } \\
\text { Cultural Rights }\end{array}$ & 160 \\
\hline $\begin{array}{l}\text { International Convention } \\
\text { on the Elimination of All } \\
\text { Forms of Racial } \\
\text { Discrimination (CERD) }\end{array}$ & 1966 & $\begin{array}{l}\text { Fundamental and } \\
\text { Human Rights for } \\
\text { Persons of All Races }\end{array}$ & 173 \\
\hline $\begin{array}{l}\text { Convention on the } \\
\text { Elimination of All Forms } \\
\text { of Discrimination Against } \\
\text { Women (CEDAW) }\end{array}$ & 1980 & $\begin{array}{l}\text { Fundamental and } \\
\text { Human Rights for } \\
\text { Women }\end{array}$ & 185 \\
\hline $\begin{array}{l}\text { Convention Against } \\
\text { Torture and } \\
\text { Other Cruel, Inhuman or } \\
\text { Degrading Treatment or } \\
\text { Punishment (CAT) }\end{array}$ & 1984 & $\begin{array}{l}\text { Freedom from Torture } \\
\text { and Other Forms of } \\
\text { Punishment }\end{array}$ & 147 \\
\hline $\begin{array}{l}\text { Convention on the Rights } \\
\text { of the Child (CRC) }\end{array}$ & 1989 & $\begin{array}{l}\text { Fundamental and } \\
\text { Human Rights for } \\
\text { Children }\end{array}$ & 193 \\
\hline
\end{tabular}

One might think states would only join ${ }^{5}$ treaties embodying principles they believe in and with goals they intend to further. But, is this true in the context of international human rights treaties? Does the fact that the majority of states have overwhelmingly committed to this international human rights regime mean that most states are also committed to protecting human rights and ensuring that those who abuse human rights are brought to justice? Or does something else explain the tendency of states to willingly commit to a regime which, at least on paper, purports to infringe on state sovereignty by requiring the state to conduct its domestic affairs in a way that will not run afoul of

\footnotetext{
4 States parties are listed as of August 2010.

5 I use the words "join" or "commit" to refer to a state's decision to ratify an international human rights treaty.
} 
treaty requirements without offering any tangible benefits according to treaty terms?

Although various theories have been advanced to explain state commitment to human rights treaties, some evidence suggests states join international human rights treaties somewhat indiscriminately and perhaps as window dressing only. ${ }^{6}$ Because many international human rights treaties have nonexistent or weak enforcement mechanisms-often only requiring that states selfreport compliance-states may view commitment as essentially costless from a sovereignty standpoint. ${ }^{2}$ In fact, scholars have

6 See, e.g., Emilie M. Hafner-Burton \& Kiyoteru Tsutsui, Human Rights in a Globalizing World: The Paradox of Empty Promises, 110 AM. J. Soc. 1373, 1374 (2005) (suggesting that states may ratify human rights treaties only for window dressing purposes, given that the average state has ratified a steadily increasing number of human rights treaties but the percentage of states reportedly repressing human rights has grown over time); Oona A. Hathaway, The Cost of Commitment, 55 STAN. L. Rev. 1821, 1856-58 (2003) [hereinafter Hathaway, Cost of Commitment] (finding that non-democratic states with poor human rights ratings are just as likely, and sometimes even more likely, to commit to international human rights treaties than non-democratic states with better human rights ratings); Oona A. Hathaway, Do Human Rights Treaties Make a Difference?, 111 YALE L.J. 1935, 1982-87 (2002) [hereinafter Hathaway, Make a Difference?] (showing, for example, that approximately the same percentage of countries with the most recorded acts of torture ratified the Convention Against Torture and Other Cruel, Inhuman or Degrading Treatment or Punishment as did countries with no recorded acts of torture).

7 For example, under the International Covenant on Civil and Political Rights, states agree to submit reports on the measures they have taken to give effect to the Covenant's provisions. International Covenant on Civil and Political Rights, art. 40, Dec. 19, 1966, 999 U.N.T.S. 171 [hereinafter ICCPR] ("The States Parties ... undertake to submit reports on the measures they have adopted which give effect to the rights recognized ...."). The texts of the five other core international human rights treaties similarly provide that states self-report compliance. See Convention on the Rights of the Child, art. 44, Nov. 20, 1989, 1577 U.N.T.S. 44 [hereinafter CRC] ("States Parties undertake to submit to the Committee, through the Secretary-General of the United Nations, reports on the measures they have adopted which give effect to the rights recognized herein and on the progress made on the enjoyment of those rights ...."); Convention Against Torture and Other Cruel, Inhuman or Degrading Treatment or Punishment, art. 19, Dec. 10, 1984, 1465 U.N.T.S. 113 [hereinafter CAT] (“The States Parties shall submit to the Committee, through the Secretary-General of the United Nations, reports on the measures they have taken to give effect to their undertakings under this Convention, within one year after the entry into force of the Convention for the State Party concerned."); Convention on the Elimination of All Forms of Discrimination Against Women, arts. 18, 21, Dec. 18, 1979, 1249 U.N.T.S. 14 [hereinafter CEDAW] (requesting States Parties to submit reports for consideration by the CEDAW Committee, and instructing the CEDAW Committee to "make suggestions and general recommendations based on the examination of reports and information received from the States Parties"); International Covenant on Economic, Social and Cultural Rights, arts. 16, 17, Dec. 
found that past and present practices (presumably indicators of the state's commitment to, and ability to comply with, the principles embodied by treaties promoting good human rights practices) are not real indicators of whether a state will join an international treaty protecting human rights. Rather, some studies have found that states with poor human rights records are often just as likely to commit as are states with good records. ${ }^{8}$ Furthermore, studies have shown that many states continue their poor practices despite the fact that they have ratified a treaty condemning such practices. ${ }^{9}$

Recently, however, the international community created an international human rights treaty with a stronger enforcement mechanism designed to induce compliance with treaty terms. In July 1998, states adopted the Rome Statute and created the International Criminal Court ("ICC"). ${ }^{10}$ The ICC is the first permanent, treaty-based international criminal court established to help end impunity for perpetrators of the most serious crimes of genocide, crimes against humanity, and war crimes. ${ }^{11}$ Unlike previous treaties, the ICC treaty contains significant, legally binding, and precise enforcement mechanisms. First, by

16, 1966, 993 U.N.T.S. 3 [hereinafter ICESCR] (enumerating the procedures states must follow when submitting "reports on the measures which they have adopted and the progress made in achieving the observance of the rights recognized" in the Covenant); International Convention on the Elimination of All Forms of Racial Discrimination, art. 9, Mar. 7, 1966, 660 U.N.T.S. 212 [hereinafter CERD] (requiring states to submit "a report on the legislative, judicial, administrative or other measures which they have adopted and which give effect to the provisions of this Convention").

8 See Hathaway, Make a Difference?, supra note 6, at 1982 ("[C]ountries with the worst Genocide ratings are just about as likely as those with the best to have ratified the Genocide Convention."); Hathaway, Cost of Commitment, supra note 6, at 1856 (finding empirical evidence to support the proposition that "countries with better human rights ratings are apparently more reluctant to commit to human rights treaties than otherwise expected and countries with poor ratings are less reluctant to do so than otherwise expected").

9 See Hafner-Burton \& Tsutsui, supra note 6, at 1378 ("As external pressures decrease, governments often spiral into worse repression after ratification, and the human rights legal regime remains powerless to stop this process.").

10 See Rome Statute of the International Criminal Court, July 17, 1998, 2187 U.N.T.S. 90 [hereinafter Rome Statute].

11 See id. pmbl. paras. 4-5, arts. 5-8. Beginning after January 1, 2017, and assuming the parties to the Rome Statute vote to amend the statute accordingly, the ICC will also have jurisdiction over the crime of aggression. See Review Conference of the Rome Statute, Amendments to the Rome Statute of the International Criminal Court on the Crime of Aggression, Resolution RC/Res.6, Annex I, I I 2, 3(3) (June 11， 2010), http://www.icc-cpi.int/iccdocs/asp_docs/Resolutions/RC -Res.6-ENG.pdf. 
committing to the ICC, states agree that the Court has automatic jurisdiction over those core crimes. ${ }^{12}$ States also agree that an independent ICC Prosecutor may initiate investigations against the state's nationals for the covered crimes either on his own with the approval of the Court's Pre-Trial Chamber, or based on referrals from a State Party or the United Nations Security Council. ${ }^{13}$ However, both the Prosecutor and the Court operate without direct United Nations Security Council oversight, and the Council has no power to veto decisions to investigate particular situations. ${ }^{14}$ In addition, the ICC has jurisdiction to prosecute even heads of state and does not recognize any immunity states may have otherwise granted to such actors who engage in criminal activity that falls within the Court's jurisdiction. ${ }^{15}$

Finally, although it is true that the ICC operates as a court of last resort, under the "complementary" provision of the Rome Statute, the ICC will obtain jurisdiction over the nationals of States Parties where the state is "unwilling or unable genuinely" to proceed with a case. 16 "Unwillingness" includes instances where national proceedings are a sham or are inconsistent with an intention to bring the person to justice, either because such proceedings are unjustifiably delayed or are not conducted independently or impartially. ${ }^{17}$ A nation's "inability" to prosecute includes instances where, because of the collapse or unavailability

12 See Rome Statute, supra note 9, arts. 5-8, 11, 12(2) (listing the crimes and explaining the Court's jurisdiction).

13 See id. arts. 13-15.

14 See Lionel Yee, The International Criminal Court and The Security Council: Articles 13(b) and 16, in THE INTERNATIONAL CRIMINAl COURT: THE MAKING OF THE Rome STATUTE 143-52 (Roy S. Lee ed., 1999) (explaining that the objective of article 13(b) of the Rome Statute is to avoid a special tribunal or oversight by the Security Council). See also Jack Goldsmith \& Stephen D. Krasner, The Limits of Idealism, DAEDALUS, Winter 2003, at 47, 53 ("[T]he ICC prosecutor and court are unaccountable to any democratic institution or elected official."); Christopher Rudolph, Constructing an Atrocities Regime: The Politics of War Crimes Tribunals, 55 INT'L ORG. 655, 679-80 (2001) (explaining that Article 16 of the Rome Statute does not give single members of the Security Council veto power, but rather only defers prosecution through a unanimous vote of the Security Council).

15 Rome Statute, supra note 10, art. 27.

16 Id. pmbl. para. 10, art. 17(1)(a).

17 Id. art. 17(2) (stating that in determining "unwillingness," the Court shall consider whether "(a) [t] he proceedings were or are being undertaken . . . for the purpose of shielding the person concerned from criminal responsibility . . . ; (b) [t]here has been an unjustified delay in the proceedings . . . ; [and] (c) [t]he proceedings were not or are not being conducted independently or impartially ... $. ")$. 
of its national judicial system, the nation cannot obtain the accused or the necessary evidence, or is otherwise unable to carry out the proceedings. 18 The Court-as opposed to States Parties to the Rome Statute-determines whether the "unwilling or unable" bases for proceeding before the ICC have been met, thus further demonstrating the strength and independence of the ICC's enforcement mechanisms.

The existence of the ICC treaty offers an excellent opportunity to test whether and how the design of international human rights treaties influences state commitment decisions. Building on the logic advanced by Oona Hathaway, ${ }^{19}$ I argue that state commitment to international human rights treaties is a function of two considerations relative to the costs of failing to comply with treaty terms: (1) the institutional design of the treaty-specifically, the strength of its enforcement mechanisms - and (2) the state's level of domestic human rights practices. States should be more likely to ratify a given treaty if (1) the treaty's enforcement mechanisms are weak (such that compliance with treaty terms may be irrelevant) or (2) the treaty's enforcement mechanisms are relatively strong, but the state's recent past and present human rights practices indicate that it can comply with treaty terms. Thus, empirically we should still see that states with bad human rights practices ${ }^{20}$ will regularly and readily commit to treaties with weak enforcement mechanisms. However, states should view stronger enforcement mechanisms as a credible threat and commit only if

18 Id. art. 17(3) (the Court will find "inability" where, "due to a total or substantial collapse or unavailability of its national judicial system, the State is unable to obtain the accused or the necessary evidence and testimony or otherwise unable to carry out its proceedings").

19 The present study goes beyond Hathaway's 2003 examination of state commitment to international human rights treaties. Hathaway purposely studied ratification of only four different treaties using two independent variables of interest-namely, a state's human rights ratings and whether or not it was a democracy - without accounting for the timing of ratifications. See Hathaway, Cost of Commitment, supra note 6, at 1849 (arguing that democratic countries are more likely to join human rights treaties than nondemocratic countries.). In a later study, Hathaway included additional variables testing commitment to several human rights treaties using a Cox proportional hazards model, though her study did not include the ICC. See Oona A. Hathaway, Why Do Countries Commit to Human Rights Treaties?, 51 J. CONFLICT RESOL. 588, 592 (2007) (maintaining that the effect of human rights treaties on states depends on the treaties' domestic enforcement and collateral consequences).

20 In the empirical tests, I use a state's human rights ratings as a proxy for its human rights practices. See infra Section 5.3 (measuring and comparing the human rights practices of various states). 
the state's rational calculations concerning the strength of its domestic human rights practices indicate that it should be able to comply with treaty terms and thereby avoid costly infringements on its sovereignty.

This Article offers the first empirical analysis of the relationship between treaty enforcement mechanisms and likelihood of ratification across a broad range of treaties. I test the credible threat theory in the context of the six main international human rights treaties and their associated articles and optional protocols, as well as the ICC treaty. I categorize the resulting fourteen treaty commitment possibilities according to five different levels of enforcement mechanisms, which range from self-reporting to the ICC treaty's independent Prosecutor and Court. ${ }^{21}$ Although the empirical results cannot be conclusive, they do provide support for the explanatory power of the credible threat theory. The results of event history analysis from 1966 to 2008 indicate that states with poorer human rights ratings more regularly commit to international human rights treaties with the weakest enforcement mechanisms. However, states with poor ratings are less likely to commit to the ICC, suggesting that states view those stronger enforcement mechanisms as a credible threat and are more likely to commit if they can comply with treaty terms. This further suggests that states with poor human rights practices may not join international human rights treaties because they do not want to be held accountable for respecting and protecting the lives of their citizenry. Rather, at least some states may ratify these treaties only because commitment costs are cheap and the consequences of noncompliance are trivial. On the other hand, where enforcement

21 As discussed in Section 4.2, some of the international human rights treaties included within this study have optional articles whereby states can agree to additional enforcement measures. For example, states may recognize the competence of a committee to consider complaints of one state against another claiming the party is not fulfilling its obligations under the treaty. See, e.g., ICCPR, supra note 6, art. 41(1) ("A State Party to the present Covenant may at any time declare under this article that it recognizes the competence of the Committee to receive and consider communications to the effect that a State Party claims that another State Party is not fulfilling its obligations under the present Covenant."). States may also recognize the competence of a committee to hear complaints by individuals alleging the state has violated treaty terms. See, e.g., CAT, supra note 6, art. 22(1) ("A State Party to this Convention may at any time declare . . . that it recognizes the competence of the Committee to receive and consider communications from or on behalf of individuals subject to its jurisdiction who claim to be victims of a violation by a State Party of the provisions of the Convention."). 
mechanisms are relatively strong, the statistical evidence indicates that calculations about the costs of commitment significantly influence state ratification behavior.

This Article is organized into six sections. Section 2 provides a brief overview of the international human rights regime. Section 3 follows with a review of the existing literature explaining state commitment to international human rights treaties. In Section 4, I discuss more fully my theory about the credible threat associated with stronger enforcement mechanisms and how that threat influences state ratification behavior. I also explain how I categorize the various treaties included in this study according to five different levels of enforcement mechanisms. In Section 5, I describe the research design of the empirical analysis. Section 6 presents the results of the statistical tests. The conclusion in Section 7 addresses implications of the empirical results and outlines avenues for future research.

\section{THE INTERNATIONAL HUMAN RIGHTS REGIME}

The international human rights regime is a relatively new creation. Only following World War II, and essentially motivated by the destruction caused by that war, did the international community focus on creating a systematic regime designed to protect the basic human rights of all individuals. ${ }^{22}$ Those basic human rights were defined in the Universal Declaration of Human Rights ("UDHR"), adopted in 1948 by the United Nations General Assembly. ${ }^{23}$ The UDHR expressed an idea that was revolutionary

22 See BOUANDEL, supra note 1 (analyzing the evolution of international human rights regimes since the Second World War); BETH A. SIMMONS, MOBILIZING FOR HuMAN RIGHTS: INTERNATIONAL LAW IN DOMESTIC POLITICS 23 (2009) (detailing the systematic process behind drafting declarations on human rights); Buergenthal, supra note 1, at 705 (discussing the rise of human rights instruments, such as the Universal Declaration of Human Rights, in the immediate aftermath of World War II); Wade M. Cole, Sovereignty Relinquished? Explaining Commitment to the International Human Rights Covenants, 1966-1999, 70 AM. SOC. REV. 472, 474-75 (2005) (relating the systematic nature of modern human rights protocols); Vreeland, supra note 1, at 71 (asserting that numerous human rights conventions, including the Convention Against Torture, arose from the legacy of World War II); Christine Min Wotipka \& Kiyoteru Tsutsui, Global Human Rights and State Sovereignty: State Ratification of International Human Rights Treaties, 1965-2001, 23 Soc. F. 724, 729 (2008) (claiming that the devastation of World War II provided an impetus for the U.N. and its member states to seek to protect universal rights, which until then had not been a pronounced or unified international goal).

23 See Jack Donnelly, International Human Rights: A Regime Analysis, 40 INT'L ORG. 599, 606 (1986) (discussing the enunciation of civil, political, economic, 
at the time: human rights were universal in character, and the international community had an obligation to ensure those rights were protected without regard to international boundaries or states' $^{\prime}$ sovereign rights. ${ }^{24}$ Although the UDHR was only a declaratory document and not binding on states, it paved the way for numerous international institutions designed to promote and protect human rights.

As noted above, the ICCPR and the ICESCR - initially drafted in 1954-are the foundation of the international human rights regime. Additional binding treaties followed the drafting of the two Covenants. For example, the International Convention on the Elimination of All Forms of Racial Discrimination ("CERD") entered into force in 1969. The Convention Against Torture and Other Cruel, Inhuman or Degrading Treatment or Punishment ("CAT") was adopted in December 1984 and entered into force in 1987 when the required number of states had ratified the treaty. The international human rights regime also expanded to include institutions aimed at protecting particular groups from systematic discrimination. Although Article 3 of the ICCPR prohibited discrimination against women, in 1979, the United Nations General Assembly adopted a comprehensive treaty designed to promote the equal rights for women and the protection of women against all forms of discrimination. That treaty-the Convention on the Elimination of All Forms of Discrimination Against Women ("CEDAW") - was opened for signature in 1980 and entered into force in 1981. The Convention on the Rights of the Child ("CRC") entered into force in 1990.25

Binding international treaties constitute the foundation and principle substance of the international human rights regime, the idea being that the binding nature of these international institutions can make them a strong and effective instrument to promote and protect global human rights. International human rights treaties are adopted and opened for signature by the United Nations General Assembly and require signatures and ratifications

social, and cultural rights in the UDHR); Vreeland, supra note 1, at 71 (positing that the content of "human rights" was principally advanced through the UDHR).

24 Wotipka \& Tsutsui, supra note 21, at 729-30 (maintaining that the UDHR and the Charter of the United Nations were the first "concerted efforts" to protect universal human rights, and that the ideas contained in the UDHR were "revolutionary in international relations and international law" for their intended universal application).

25 See U.N. Human Rights Treaties, supra note 3. 
by a particular number of countries in order to enter into force. Only by ratifying or acceding to the treaty (which is the process states use where they have not previously signed the treaty) are states legally bound by treaty terms. Furthermore, a government's ability to ratify a treaty depends on its own domestic rules regarding ratification: some governments may bind their states to treaties based only on the will of a chief executive while others need the approval of a significant vote of a legislative body or bodies. Finally, until they enter into force, treaties have no binding effect on governments.

These international human rights treaties usually have some enforcement mechanism that is ostensibly designed to hold states accountable to their treaty commitments. In the international human rights context, that enforcement mechanism is most typically under the control of a committee of experts established pursuant to the text of the treaty. Although terms differ, most treaties provide for a committee to monitor state compliance by examining reports that states are required to submit commenting on their own human rights practices. Committees reviewing these reports can typically question states about them and also make comments about the state's level of treaty compliance. However, the committees have no power to order sanctions or otherwise punish states for their failure to live up to treaty terms. Thus, states that file even the most perfunctory of reports likely have sufficiently complied with treaty terms. ${ }^{26}$

Some treaties and protocols, however, allow states to bind themselves to additional committee oversight of their practices. States can agree on the committee's competence to hear complaints by other states claiming that they are not living up to their obligations under the treaty. ${ }^{27}$ Some treaties further allow states to agree on the committee's competence to hear complaints by individuals alleging that their rights under the treaty have been violated - if the individuals have, among other things, exhausted

26 Jack Donnelly, InTERnational Human Rights 85 (3d ed. 2007) (noting both the benefits and shortcomings of the reporting procedure of the ICCPR's Human Rights Committee).

27 See CAT, supra note 6, art. 21 ("A State Party to this Convention may at any time declare under this article that it recognizes the competence of the Committee to receive and consider communications to the effect that a State Party claims that another State Party is not fulfilling its obligations under this Convention."); ICCPR, supra note 6, art. 41 (similar). 
available domestic remedies. ${ }^{28}$ Finally, some treaties provide that states can recognize the competence of the committee to visit their territory and grant the committee access to relevant information about potential violations of the rights protected by the treaty. ${ }^{29}$ In each of these cases, the state binds itself to increasingly greater impositions on its sovereign rights to regulate domestic affairs. In addition, if a state cannot be persuaded to comply with the committee's recommendations regarding complaints or other violations uncovered during any investigations, the committee can issue reports about the state's non-compliance and possibly also make a public statement on the matter. ${ }^{30}$ However, the committees have "no authority to act punitively against the offending state, or impose any sanctions" for noncompliance. ${ }^{31}$

In recent years, however, the scope of the international human rights regime has broadened. Until the 1990s, most treaties had as their primary focus holding governments, as opposed to individuals, accountable for ensuring the protection of human rights within their states, not only by promoting good human rights standards, but also by punishing those who violated the

\footnotetext{
28 By committing to the First Optional Protocol to the ICCPR, states may agree that individuals can bring complaints against them alleging violations of the ICCPR. See Optional Protocol to the International Covenant on Civil and Political Rights, art. 1, Dec. 19, 1966, 999 U.N.T.S. 302 [hereinafter ICCPR First Optional Protocol]. Similar provisions are contained in Article 14 of the CERD, supra note 6; Article 22 of the CAT, supra note 6; and in the Optional Protocol to the CEDAW. See Optional Protocol to the Convention on the Elimination of All Forms of Discrimination Against Women, art. 2, Oct. 6, 1999, 2131 U.N.T.S. 83, 97 [hereinafter CEDAW Optional Protocol].

29 In committing to the Optional Protocol to the CAT, a state recognizes the competence of the Subcommittee on Prevention to regularly visit any place under the state's jurisdiction and control where persons are held in detention by the government or with its acquiescence. See Optional Protocol to Convention Against Torture and Other Cruel, Inhuman or Degrading Treatment or Punishment, arts. 4, 11, Dec. 18, 2002, 2375 U.N.T.S 237 [hereinafter CAT Optional Protocol].

30 See ICCPR First Optional Protocol, supra note 27, arts. 5, 6 (establishing the Human Rights Committee's procedural guidelines following submission of an individual communication, including summarizing its activity in its annual report); CEDAW Optional Protocol, supra note 27, arts. 7, 12 (similar, with regard to the CEDAW Committee).

31 Henry J. Steiner, Individual Claims in a World of Massive Violations: What Role for the Human Rights Committee?, in THE Future OF UN HUMAN RIGHTS TREATY MONITORING 15, 36-37 (Philip Alston \& James Crawford eds., 2000).
} 
standards imposed. ${ }^{32}$ Recognizing that some governments either were the rights violators or were essentially powerless to protect their citizenry from the abuses meted out by some groups or criminal organizations, the international community actively turned towards creating an institution that would help to end impunity for mass atrocities where states themselves were either unwilling or unable to do so. In this regard, and after many years of negotiations, in July 1998 during a United Nations conference in Rome, states adopted a treaty-the Rome Statute-creating the International Criminal Court. ${ }^{33}$ In July 2002 after the required sixty states had ratified the Rome Statute, the ICC came into existence. ${ }^{34}$ States committing to the ICC treaty agree to cede to an independent Prosecutor the power to prosecute the state's own nationals for mass atrocities should the Prosecutor and the ICC's Pre-Trial Chamber determine the state is unwilling or unable to do so domestically.

\section{EXISTING LITERATURE ON STATE COMMITMENT TO INTERNATIONAL HUMAN RIGHTS TREATIES}

A number of scholars have offered theories to explain why states might decide to ratify treaties designed to hold the state to domestically promoting and protecting human rights. I group that literature under the following two labels: (1) the "rationalist view" and (2) the "external pressures view." Within the "rationalist view," I include theories that focus primarily on the direct costs and benefits of treaty commitment. Under this view, states will commit to treaties where the costs of commitment are low, where compliance is otherwise not costly because the state can comply with treaty terms, or where commitment costs are outweighed by specific domestic benefits the state may derive by binding itself to the treaty's terms. Under the "external pressures view," I include theories that look beyond direct cost and benefit calculations to explain treaty commitment. For example, even where a state

32 See Buergenthal, supra note 1, at 717-20 (discussing the expanded the concept of international responsibility for violations of human rights, which now includes individuals and groups in addition to governments).

33 See Mahnoush H. Arsanjani, The Rome Statute of the International Criminal Court, 93 AM. J. INT'L L. 22, 23 (1999) (outlining the negotiation process which culminated in the Rome Conference).

34 See generally WILLIAM A. SCHABAS, AN INTRODUCTION TO THE INTERNATIONAL CRIMINAL COURT (3d ed. 2007) (describing the origins, initial rulings, and functioning of the International Criminal Court). 
cannot comply with treaty terms, it may be persuaded that ratifying treaties embracing positive norms may be the appropriate thing to do if the state wants to be viewed as a legitimate player on the world stage and one worthy of obtaining extra-treaty benefits, such as aid and trade. ${ }^{35}$ Richer and more powerful states may also pressure other weaker states to join international human rights treaties by threatening to withhold extra-treaty benefits if the state does not at least signal its intention to abide by international norms calling for states to domestically protect against human rights abuses.

\subsection{The Rationalist View}

Under a rationalist view, states will consider their own material interests and only join treaties where the costs of commitment are small or outweighed by benefits that can be derived from that commitment. ${ }^{36}$ States may calculate those costs, however, in more or less retrospective or prospective ways. States may look to their past practices and actions as a guide to determining whether treaty commitment is likely to be relatively costless even if enforcement mechanisms are strong. On the other hand, even if a state's past and present human rights practices suggest that compliance with treaty terms may be difficult, a state's commitment decisions may be guided by rational calculations about whether binding itself to the treaty's terms can provide overriding future benefits.

\subsubsection{Rationalist and Retrospective Calculations}

\subsubsection{Domestic Practice and Policy Compliance Costs}

For example, scholars advancing a rationalist view of state ratification behavior suggest that states will avoid costly commitments and be more likely to join treaties with which they can easily comply and which will impose few, if any, limitations on their sovereignty. Indeed, George Downs, David Rocke, and Peter

35 See, e.g., JAMES G. MARCH \& JOHAN P. OlsEN, REDISCOVERING INSTITUTIONS: The Organizational BASIS OF POLITICS 160-62 (1989) (discussing political institutions and how they function, how they affect political life, how they change, and how they might be improved).

36 See, e.g., Andrew T. Guzman, A Compliance-Based Theory of International Law, 90 CAL. L. REV. 1823, 1860 (2002) (suggesting that the rationalist view of state behavior provides predictions about how countries will act inasmuch as it assumes that states weigh the costs and benefits of their actions and proceed where benefits outweigh costs). 
Barsoom argue that the primary reason we may see widespread compliance with many treaties is because states have a tendency to join only those treaties that do not require them to depart from what they would have done in the absence of the treaty. ${ }^{37}$ In short, states will view compliance costs - and the concomitant loss to state sovereignty - as minimal and will tend to join treaties with which their past and present practices and policies are already consistent. ${ }^{38}$

In the case of international human rights treaties, state calculations about policy similarity and compliance costs will likely center on the state's domestic political configuration and its past and present human rights practices. In fact, much literature suggests that democracies generally should be more likely than autocracies to commit to treaties requiring them to protect against human rights abuses. After all, democratic states generally protect basic human rights, apply the rule of law fairly, and limit state power. Therefore, for those states, ratification of human rights treaties should be essentially costless since commitment will produce little, if any, change to the status quo ante. ${ }^{39}$ For autocratic regimes, however, ratification may be quite costly. Because autocratic regimes tend not to place legal restraints on their own power, commitment to international human rights treaties could require significant policy change in order to ensure the state does not run afoul of treaty terms, policies, and goals. ${ }^{40}$ Even aside from a state's domestic political configuration, however, a state's practices and policies regarding individual human rights should enter into rational compliance cost calculations. States with a recent history of better human rights practices should find commitment less costly, and the risks to state sovereignty of noncompliance less significant, than states with a history of worse practices. ${ }^{41}$

37 George W. Downs, David M. Rocke \& Peter N. Barsoom, Is the Good News about Compliance Good News about Cooperation?, 50 INT'L ORG. 379, 383 (1996) (explaining the major limitations on the inferences that can be drawn from the compliance evidence alone).

38 Id. (emphasizing that states will rarely spend a great amount of time and effort in negotiating agreements that will continually be violated).

39 See Cole, supra note 22, at 475-76.

40 See id. (contrasting autocratic regimes with democracies).

41 See id.; Wotipka \& Tsutsui, supra note 22, at 737-38 (summarizing the hypothesis that correlates extant human rights practices and policies with the likelihood of treaty ratification). 
Along these same lines, Christine Wotipka and Kiyoteru Tsutsui argue that compliance with human rights norms may be easier for wealthier and more developed countries since those countries may already have in place policies permitting ready compliance with most international human rights treaties. ${ }^{42}$ They note that economically developed countries tend to be more politically stable and also have citizens who embrace progress and post-materialist values - such as the need to protect citizens against human rights abuses. ${ }^{43}$ On the other hand, countries that are less economically developed may not be able to devote sufficient resources to ensuring that human rights are protected, particularly if the economic situation also leads to violence or political instability. Those states may find that compliance with international human rights treaties would require a substantial commitment to policy change - a fact that may cause them to avoid ratifying.

Finally, the costs of complying with international human rights treaties may be reduced even for states with practices and policies that do not conform to treaty terms where the mechanisms to enforce compliance are weak or nonexistent. ${ }^{44}$ To the extent that enforcement mechanisms are not strong enough to hold states to their commitment and punish bad and noncompliant behavior, even rights-abusing states may rationally conclude that commitment is warranted and also relatively costless.

Indeed, some empirical evidence supports the notion that state commitment decisions are influenced at least in part by states'

42 Wotipka \& Tsutsui, supra note 22, at 737 (summarizing the hypothesis that a state's likelihood of ratifying human rights treaties increases as the level of development and their citizens' awareness of human rights increases).

43 See generally RonAld IngleHART, THE Silent Revolution: CHANGing VAlues AND POlitical StYles AmONG Western Publics (1977) (analyzing the shift in value of Western publics from an emphasis on material well-being and physical security towards greater emphasis on the quality of life); RONALD INGLEHART, CULTURE SHIFT IN ADVANCED INDUSTRIAL SOCIETY (1990) (examining the changes in public opinion toward religious beliefs, motives for work, and various social issues, such as divorce and abortion).

44 See Hathaway, Cost of Commitment, supra note 6, at 1832, 1834-36 (observing that states with poor human rights practices, in some cases, ratify human rights treaties where the cost of complying with the treaty, as determined by the strength of its enforcement and monitoring mechanisms, are low). Cf. Downs, Rocke, \& Barsoom, supra note 36, at 383, 388-92 (finding that a treaty may have weak or nonexistent enforcement mechanisms where the terms of the treaty do not bind participant states to any more than that to which those states would have otherwise committed). 
perceptions about the strength of the treaty's enforcement mechanisms. In her study examining state commitment to four different human rights treaties requiring only that states report their level of compliance, Oona Hathaway found that nondemocracies with poor human rights ratings were just as likely, and sometimes even more likely, than non-democracies with better human rights ratings to ratify. Hathaway attributed this finding to the treaties' weak enforcement mechanisms and also the absence of domestic enforcement mechanisms in the form of an active and vocal civil society or others who ordinarily push for better practices in democracies. ${ }^{45}$ On the other hand, my own statistical tests of ICC commitment using event history analysis showed that states with worse human rights practices and non-democracies were less likely to join the Court than were states with better practices. 46 These findings suggest that where enforcement mechanisms are stronger-as they are in the ICC treaty-states will be more likely to ratify only where their compliance cost calculations suggest they can comply with treaty terms and avoid costly sovereignty losses.

\subsubsection{Costs of Domestic Ratification Processes}

Beth Simmons identifies the political domestic ratification process as another cost that governments may calculate when deciding whether to commit to international treaties. ${ }^{47}$ In order to bind themselves to international treaties, states must follow

45 See Hathaway, Cost of Commitment, supra note 6, at 1856 (asserting that, because democratic states generally have "stronger internal enforcement mechanisms" than non-democratic states, democracies and non-democracies are likely to have disparate commitment patterns).

46 See Yvonne M. Dutton, Explaining State Commitment to the International Criminal Court: Strong Enforcement Mechanisms as a Credible Threat, 10 WASH. U. GLOB. STUD. L. REV. 477, 482 (2011) (arguing that commitment to an international human rights treaty is a function of the strength of the treaty's enforcement mechanism and of the strength of a state's internal policies and enforcement mechanisms). The results of event history analysis showed that a state's level of human rights practices was a highly significant and positive predictor of ICC treaty ratification. $I d$. at 520 . In fact, with each unit increase in a state's human rights rating, the state became between $30 \%$ and $38 \%$ more likely to commit to the ICC. Id. The results also showed that democracies were more likely than nondemocracies to join the Court. Id. at 521-23.

47 See SimMONS, supra note 22, at 68 (identifying as "legal integration costs" those costs that stem from executive-legislative relations, those that stem from the nature of the legal system itself, and those that stem from power-sharing in federal systems). 
whatever domestic processes are required to make any ratification legal and legitimate. The political costs associated with treaty ratification will be lowest, as Simmons notes, when the government fully controls the process, such as where the head of state has the sole right to make ratification decisions. ${ }^{48}$ States that must undertake a more onerous process, however, may find treaty ratification politically more costly. Indeed, as in the United States, some states may require an affirmative supermajority vote of their legislature before the government is permitted to bind itself to an international treaty. Where the number of domestic "legislative veto players" is larger, governments may face opposition to, or delays in, the treaty ratification process that can make ratifying an international human rights treaty too politically costly to pursue. ${ }^{49}$

\subsubsection{Rationalist and Prospective Calculations}

\subsubsection{Future Domestic Uncertainty Costs}

By contrast to the rationalist theories discussed above, which emphasize the backward-looking calculations states may engage in when making commitment decisions, some rationalist theories instead focus on more prospective and forward-looking calculations. For example, treaty ratification may cause some states-particularly those that follow a common law legal tradition-to incur future domestic uncertainty costs. ${ }^{50}$ In the common law tradition, as opposed to the civil law tradition, the judiciary is generally independent from the government and there is some possibility that it will apply treaty law in a way that creates

48 Id. (noting that in such instances, where the executive has sole prerogative both to negotiate and to ratify a treaty, "ratification follows virtually automatically from the signing of the text").

49 See id. at 68-69 (noting that the higher the number of legislative veto players in a state, the higher the "ratification hurdle" and the less the state is likely to ratify an international agreement).

50 See id. at 71 (arguing that features typical to common law systems, including an emphasis on judge-made law and judicial independence, result in legal dualism and thus provide incentives for governments to take a slower approach to treaty ratification); see also Jay Goodliffe \& Darren G. Hawkins, Explaining Commitment: States and the Convention Against Torture, 68 J. POL. 358, 364 (2006) (explaining that judges in common law judicial systems may apply international treaties by drawing on legal sources beyond a statutory code, thus creating unintended commitment costs for states). 
new government obligations to the state's citizens and others. ${ }^{51}$ Therefore, even for states with present practices and policies that would otherwise make compliance with treaty terms relatively costless, this future uncertainty about how treaty law will be applied after ratification may cause common law states to be wary of ratifying international human rights treaties.

\subsubsection{Future Hand-Tying Benefits}

\subsection{Credible Commitment}

Other scholars suggest that states may rationally commit to certain international human rights treaties in order to obtain future hand-tying benefits - notwithstanding that their past and present domestic political configurations and prevailing human rights practices suggest an inability to comply with treaty terms. In their study of state commitment to the ICC, Beth Simmons and Allison Danner argue that for non-democracies with poor human rights practices, the sovereignty costs of joining the Court are outweighed by the potential future benefits the state can obtain by binding itself to the ICC treaty's strong enforcement mechanisms. ${ }^{52}$ Specifically, by ratifying the ICC treaty, those autocratic states with poor human rights practices can credibly commit to their domestic audiences to end their past cycles of violence and, instead, respond non-violently to crises in the future. ${ }^{53}$ Simmons' and Danner's statistical results from event history analysis produce some support for their theory. They find that states that have recently experienced mass atrocities and that have poor practices are likely to join the ICC as long as those states also have weak institutions of domestic accountability. ${ }^{54}$

51 SIMMONS, supra note 22, at 73-74 (“[A] greater range of interpretative possibilities from a highly independent judiciary makes it more difficult to know ex ante how any particular treaty will be interpreted.").

52 See Beth A. Simmons \& Allison Danner, Credible Commitments and the International Criminal Court, 64 INT'L ORG. 225, 233-36 (2010) (noting that governments that face domestic turmoil and suffer from weak domestic enforcement mechanisms may commit to international treaties with strong enforcement provisions in order to credibly commit to a peaceable domestic agreement).

$53 \mathrm{Id}$. at 234 ("Joining the ICC greatly enhances the risk for states of future punishment of their senior leaders, at least by comparison to a regime of impunity.").

54 Id. at 252-53. Though Simmons and Danner did find support for their theory, one can question whether they used the best measure for a state's tendency to commit mass atrocities. They measured this concept using data on 
Nevertheless, I am more persuaded by the logic of the theories positing that states will be more backward-looking in calculating the costs of committing to international human rights treaties. According to those theories, states will commit only where their calculations indicate they can presently comply with treaty terms unless, of course, treaty enforcement mechanisms are so weak that bad and noncompliant behavior cannot be punished. It is true that some states may decide to join the ICC despite their bad practices and so as to force themselves to be better in the future. But, autocracies may not overwhelmingly decide to act in this manner. Rather, since autocratic regimes with bad practices have declined to limit their power domestically, those states may not be inclined to relinquish their sovereignty to an international institution that can punish them for practices they may not have made punishable domestically. While such states may rationally conclude that committing to treaties with weak enforcement mechanisms is relatively costless, committing to an international institution with strong enforcement mechanisms that can punish bad and noncompliant behavior is another matter. Indeed, Hathaway's study showed that autocratic states with bad human rights practices regularly commit to international human rights treaties with very weak enforcement mechanisms-mechanisms that would not enable them to signal to their domestic audiences any real credible commitment to change their policies and practices. ${ }^{55}$

whether the state had experienced a civil war with more than twenty-five deaths per year during the period between 1990 and 1998. Id. at 238. However, twentyfive battle deaths in one year does not necessarily capture "violent states" or states at risk of committing mass atrocities since twenty-five battle deaths is not a very large number and does not address whether the government is responsible for those deaths as a result of any "criminal" action or other poor practices. Nor are twenty-five battle deaths sufficient to constitute a civil war as most scholars understand it. Rather, the widely-used Correlates of War dataset classifies civil wars as those having at least one thousand war-related casualties per year of conflict. See Meredith Reid Sarkees, Codebook for the Intra-State Wars v.4.0: Definitions and Variables 1-2, COW, http://www.correlatesofwar.org/ COW2\%20Data/WarData_NEW/Intra-StateWars_Codebook.pdf (last visited Oct. 12, 2012); Meredith Reid Sarkees, The COW Typology of War: Defining and Categorizing Wars (Version 4 of the Data) 5, COW, http://www.correlatesofwar.org/COW2\%20Data/WarData_NEW/COW\%

20Website\% 20-\%20Typology\%20of\%20war.pdf (last visited, Oct. 12, 2012).

55 See Hathaway, Cost of Commitment, supra note 6, at 1856-57 (" $[\mathrm{N}]$ ondemocratic nations with worse human rights ratings are not much less likely - and are even occasionally more likely - to commit than nondemocratic nations with better ratings. ... [I]f we . . . settle for toothless treaties, nations with poor human rights records - especially nondemocratic nations - may join them to gain an expressive benefit with no intention of actually complying."). 
Accordingly, I expect that non-democracies with poor practices will typically be more backward-looking in rationally calculating the costs associated with joining an international human rights treaty and be wary of joining treaties other than those with weak enforcement mechanisms.

\subsection{Democratic Lock-In}

Finally, Andrew Moravcsik also theorizes that some states will have reasons to be forward-looking in rationally calculating the costs and benefits of treaty commitment. Moravcsik suggests that for newly transitioning democracies, the sovereignty costs associated with joining international human rights treaties can be outweighed by the benefits of locking in the treaty's principles and thereby constraining the activities of future governments that may seek to subvert democracy. ${ }^{56}$ In his study of state commitment to the European Convention for the Protection of Human Rights and Fundamental Freedoms, he found that dictatorships and established democracies voted against binding human rights guarantees during treaty negotiations, whereas the newly created democracies supported binding guarantees. ${ }^{57}$ Accordingly, some newly democratic countries may conclude that the costs of complying with international human rights treaties are relatively low since they would have adopted-or at least intended to adopt-domestic policies that are consistent with treaty terms. Furthermore, the benefits that new democracies may realize by locking future governments in to following their liberal policies may outweigh the risk that the state may not be able to immediately and fully comply with treaty terms. Nevertheless,

\footnotetext{
56 See Andrew Moravcsik, The Origins of Human Rights Regimes: Democratic Delegation in Postwar Europe, 54 INT'L ORG. 217, 225-30 (2000) (presenting the "republican liberal" explanation of the benefits of commitment to international treaties, and arguing that "recently established and potentially unstable democracies" facing real threats from nondemocratic domestic groups are the regimes most likely to accept a reduction in sovereignty in exchange for a reduction in political uncertainty).

$57 \mathrm{Id}$. at 232-233 (identifying Austria, France, Italy, Iceland, Ireland, and Germany - states only continuously democratic beginning between 1920 and 1950 - as "new democracies" voting against the ECHR). Cf. Edward D. Mansfield \& Jon C. Pevehouse, Democratization and International Organizations, 60 INT'L ORG. 137, 138 (2006) (arguing that newly democratizing nations are especially likely to enter international organizations because doing so would allow the state to "credibly commit to carry out democratic reforms and ... reduce the prospect of reversions to authoritarianism").
} 
scholars empirically examining state commitment to the Convention Against Torture and the ICC treaty found little support for the explanatory power of the democratic lock-in theory. ${ }^{58}$

\subsection{The External Pressures View}

According to some other theories, states will commit to international human rights treaties even if rational cost and benefit calculations show that compliance with treaty terms may be difficult or impossible-meaning that a state could risk significant sovereignty losses if the treaty contains strong enforcement mechanisms. In addition to the general pressure to act appropriately and consistently with international norms, states may experience external pressures from others - such as powerful states, non-governmental organizations, and civil society - to join international institutions embodying and furthering these norms. Although they would prefer to guard their sovereignty and avoid constraints on their ability to govern domestically, states may join international human rights treaties in the hopes that ratification will make them appear more legitimate, and thus worthy of extratreaty benefits such as investment, aid, and trade.59 As Emilie M. Hafner-Burton notes, many states are required to commit to

58 See Goodliffe \& Hawkins, supra note 49, at 365 (finding no statistically significant correlation between the age or stability of a democracy or the volatility of the regime and the likelihood of signing or ratifying the CAT); Jay Goodliffe \& Darren Hawkins, A Funny Thing Happened on the Way to Rome: Explaining International Criminal Court Negotiations, 71 J. PoL. 977, 994 (2009) (finding a "lack of correlation" between countries' level of democracy and support for the International Criminal Court, and thus no strong evidence for Moravcsik's lock-in hypothesis).

59 See, e.g., Goodliffe \& Hawkins, supra note 49, at 361 (describing this "logic of consequences" explanation of incentivized behavior); Beth A. Simmons, International Law and State Behavior: Commitment and Compliance in International Monetary Affairs, 94 AM. POL. SCI. REV. 819, 819-20 (2000) (arguing that reputational concerns drive international treaty compliance); SIMMONS, supra note 22 , at 77 (suggesting that governments may have no intention of complying with treaty obligations and instead have ulterior motives for ratifying treaties such as the expectation of positive publicity stemming from ratification or the expectation that more tangible benefits, such as favorable trade terms, will flow from ratification); Wotipka \& Tsutsui, supra note 22, at 734-35 (explaining that ratification follows from weaker states' desire to demonstrate their legitimacy and credibility to more powerful states in order to receive benefits from powerful states). 
improving certain domestic human rights practices in order to obtain the benefits of certain preferential trade agreements. 60

States may also be pressured directly or indirectly to commit to the treaties their neighbors ratify so as to signal that they are legitimate members of the region. Thus, even if a state cannot comply with treaty terms, it may conclude that appearing like its neighbors can produce other extra-treaty benefits-for example, participation in regional trade arrangements ${ }^{61}$ - that can outweigh the sovereignty costs of commitment, at least where treaty enforcement mechanisms are weak.

\section{COMPLIANCE COSTS AND THE CREDIBLE THREAT OF STRONG ENFORCEMENT MECHANISMS}

\subsection{The Credible Threat Theory}

My argument about state commitment to international human rights treaties is in the rationalist family, but is retrospective in nature. I argue that a state's decision about whether to join international human rights treaties depends on whether the state has been good so far, not on whether the state would like to be good in the future. I suggest states will view treaties with stronger enforcement mechanisms as a credible threat and will be more likely to commit only if their rational calculations about their past behavior suggest they will be able to comply with treaty terms. I pit the credible threat theory against the two other main alternative theories described above which seek to explain state commitment to international human rights treaties: (1) the rationalist and prospective credible commitment theory advanced by Simmons and Danner in their study of ICC commitment; and (2) the external pressures theories.

My credible threat argument has two main components: (1) the strength of the anticipated enforcement mechanism, and (2) the state's ability to comply with the terms of the treaty. As to the first component, I focus on enforcement mechanisms because it is through enforcement mechanisms that states can be held to their

60 Emilie M. Hafner-Burton, Trading Human Rights: How Preferential Trade Agreements Influence Government Repression, 59 INT'L ORG. 593, 595 (2005) (asserting that preferential trade agreements that implement "hard" standards and a "conditional supply of valuable goods" are more effective than softer human rights agreements in changing the basic conduct of repressive governments).

61 See, e.g., Goodliffe \& Hawkins, supra note 49, at 361 (describing the "logic of consequences" view of state's decision to ratify an international treaty). 
commitment agreeing to further the treaty's goals and protect individual human rights. I define an enforcement mechanism ${ }^{62}$ as the formal grant of power from states to some entity or institution with authority to oversee state compliance with treaty terms. The weakest enforcement mechanisms lack clear obligations, precision, or a precise delegation of authority or responsibility - "soft law" in the language of Kenneth Abbott and Duncan Snidal.63 Stronger, "hard law" enforcement mechanisms are precise and binding and, for example, will contain a formal grant of power to a committee or court to engage in authoritative, institutionalized, and legally binding decision-making. ${ }^{64}$ As Darren Hawkins argues, strong enforcement mechanisms provide for authorized decision-makers who are "officially empowered by states to interpret and apply the rule of law, and control resources that can be used to prevent abuses or to punish offenders." 65 States should view strong enforcement mechanisms as a credible threat and be wary of committing to treaties with such mechanisms unless they can comply with treaty terms because non-compliance can be costly.

As to the second component-ability to comply, I focus primarily on a state's record of human rights practices. I argue that states rationally calculating their ability to comply with treaty terms should consider their past and present human rights practices since that record can provide information about how the state or its leaders will likely behave in the future. Where an international human rights treaty contains stronger enforcement mechanisms, states should view the treaty as a credible threat and

62 For this discussion about enforcement and legalization, I draw on the work of several scholars. See Darren Hawkins, Explaining Costly Institutions: Persuasion and Enforceable Human Rights Norms, 48 INT'L STUD. Q. 779, 781 (2004) (explaining that for enforcement to occur, the states must give agents power to "interpret and apply" the law and to use resources to "prevent abuses or punish offenders."); Kenneth W. Abbott et al., Legalization and World Politics: An Introduction, 54 INT'L ORG. 401, 418 (2000) (noting centralized enforcement mechanisms in which international agencies have the power to withhold benefits, technical assistance, or rights of participation to violators); Donnelly, supra note 23, at 603-05 (stating that the enforcement of international norms is one of the primary "international decision-making activities" and involves stronger forms of international monitoring).

63 Kenneth W. Abbott \& Duncan Snidal, Hard and Soft Law in International Governance, 54 INT'L ORG. 421, 422-24 (2000) (explaining that the sphere of "soft law" begins once legal arrangements are weakened along one or more of the dimensions of obligation, precision, and delegation).

64 Id.

65 Hawkins, supra note 61 , at 781. 
be more likely to commit only if they intend to and can comply with the treaty's terms. Where enforcement mechanisms are weak, however, states may rationally commit regardless of their ability to comply with treaty terms.

For several reasons, my credible threat argument is centered on compliance costs specifically derived from the treaty text and states' backward looking calculations about the potential for compliance with treaty terms. First, I emphasize costs, as opposed to any benefits states may obtain by commitment, because on the whole, by their terms, international human rights treaties do not provide tangible reciprocal benefits to their members. ${ }^{66}$ Instead, states should expect to have constraints imposed on how they can act domestically towards their citizens, unless those states have already imposed those same domestic constraints upon themselves. Thus, commitment to international human rights treaties requires the state to bind itself to act in a certain way. It is true that by self-binding, states can hope to obtain the benefit of encouraging other states to also bind themselves to respecting human rights. And the ultimate outcome of all that binding may be a more peaceful world and one in which states do not have to engage in costly interventions to help "solve" other states' human rights abuses. It is also true, as the external pressure theories predict, that some states may join treaties because they hope to obtain extra-treaty benefits such as increased aid or trade. However, while a state might be rational in ratifying toothless treaties for those reasons, the credible threat theory predicts that where enforcement mechanisms are stronger, states will first determine whether they can comply with treaty terms and thus avoid a costly loss of sovereignty. Therefore, because international human rights treaties by their terms purport to constrain state domestic behavior, and because states can face a significant loss of sovereignty should they violate treaty terms-as long as enforcement mechanisms are strong-I expect states will first be concerned with compliance costs when making ratification decisions.

Second, I focus on the costs that flow from the treaty's terms, rather than costs a state might incur when deciding to ratify any

66 See Hathaway, Cost of Commitment, supra note 5, at 1823 (noting that international human rights treaties differ from arms control agreements and trade agreements which, by their terms, provide concrete reciprocal benefits to states in exchange for their commitment to act in particular ways). 
treaty - such as domestic ratification costs relating to the number of legislative veto players-because those terms are the primary guide of a state's obligations and the risks it faces if it fails to comply with those obligations. In addition, although in some cases states may look to other similar treaties or the actions of treaty bodies that oversee compliance with other similar treaties to help them interpret the actual strength and meaning of a treaty's enforcement mechanisms, it is the actual treaty terms that describe the enforcement mechanisms that will be applied to ensure compliance with that treaty. Moreover, as to the ICC specifically, since the ICC treaty is relatively new, states can really only look to the treaty's terms for information about the strength of the treaty's enforcement mechanisms to punish bad and noncompliant behavior.

Finally, my credible threat argument concentrates on retrospective, backward-looking cost calculations, rather than the prospective calculations Simmons and Danner argue to explain ICC commitment, for the reasons stated in Section 3.1.2.2.1 above. Briefly, however, the very fact that an autocratic regime has refused to implement domestic laws requiring it to improve its practices or put in place other checks on its powers-by, for example, appointing an independent judiciary-suggests that it may not wish to commit itself to an international institution that could impose restraints on its domestic behavior. Yet, that is precisely the argument of the credible commitment theory: autocracies with bad human rights practices will want to bind themselves to a strong international enforcement mechanism in order to tie their hands and force them to be good in the future. While this theory may explain the behavior of some autocratic states with bad practices, it seems reasonable to expect that most states with these characteristics would not want to take the gamble that they will not live up to their commitment and risk a loss of sovereignty. Thus, the prediction of the credible threat theory is essentially the opposite of the prediction of the credible commitment theory. I expect to find that autocratic states and states with worse human rights practices will readily commit to international human rights treaties with weak enforcement mechanisms, but will be wary of committing to treaties with strong enforcement mechanisms like those contained in the ICC treaty. ${ }^{67}$

67 See Hathaway, Cost of Commitment, supra note 5, at 1856-57 (finding that states with worse human rights practices are less likely to comply with human 


\subsection{Categorizing Levels of Enforcement Mechanisms in International Human Rights Treaties}

I test the credible threat theory empirically using the six main international human rights treaties (together with their articles and optional protocols), as well as the ICC treaty. Below, I first describe the five different levels of enforcement mechanisms found in those treaties. I then categorize the different treaties, articles, and optional protocols used in this study according to those five different levels.

Most international human rights treaties are characterized by "soft law" enforcement mechanisms. ${ }^{68}$ While many provide for an independent body to oversee compliance and enforcement, most do not grant those independent bodies - typically committeesany legally binding authority to punish bad and noncompliant behavior. The six main international human rights treaties contain what I characterize as the very weakest enforcement mechanisms: they only require the state to submit regular reports to a committee about the state's efforts to comply with treaty terms. Self-reporting requirements are particularly weak enforcement mechanisms because they lack clear and precise obligations, and moreover, the body to which states have delegated authority to consider the reports has no power to absolutely compel reports-or, for that matter, better domestic human rights practices. Indeed, as Jack Donnelly notes, the committees cannot even ensure that the required reports are submitted on time. ${ }^{69}$ Furthermore, by filing even a pro forma report, the state will have formally discharged its reporting requirement since "whatever the quality of the report, once it has been reviewed, the monitoring process typically ends until the next report is due, in five years."70 Donnelly further explains that while reporting procedures are useful in that they provide a concrete reminder for states to review their practices, those procedures cannot be used to force recalcitrant states into actually improving their practices. ${ }^{71}$

rights treaties with stronger enforcement mechanisms and are more likely to comply with treaties with "toothless" enforcement mechanisms).

68 See Abbott \& Snidal, supra note 62, at 422-24 (noting that the majority of international laws are deemed "soft law" and explaining the justifications and benefits of using soft law enforcement mechanisms in international law).

69 DONNELLY, supra note 26, at 85.

70 Id. (discussing the Human Rights Committee).

71 Id. at 87. 
States can, however, agree to be bound by more onerous enforcement mechanisms beyond simply state-reporting. First, states can agree on a committee's competence to hear complaints by other states claiming that they are not living up to their obligations under the treaty. ${ }^{72}$ On paper, this enforcement mechanism appears stronger than the self-reporting requirement since it at least requires state parties to submit to a grievance procedure before an independent committee. Nevertheless, it bears noting that in the present system, committees are not empowered to order a remedy for any violations they find: if the matter cannot be resolved via negotiation, the committee is generally limited to summarizing its activities in a report. ${ }^{73}$

In addition, some treaties allow states to agree on a committee's competence to receive and consider complaints by individuals alleging that their rights under the treaty have been violated - if the individuals have, among other things, exhausted available domestic remedies. ${ }^{74}$ The individual complaints are heard by a committee empowered to consider evidence and issue decisions. In some cases, the committee may also invite the state party to submit written responses to the views stated in the committee's decision and to comment on action taken as a result. ${ }^{75}$ However, even then, none of these optional procedures associated with the six main international human rights treaties grants to the committee any powers to issue legally binding decisions. Instead, committee powers are essentially limited to encouraging

72 For example, under Article 41 of the ICCPR, states may authorize the Human Rights Committee to hear interstate complaints, but only if both state parties have formally acknowledged the Committee's competence to receive and consider inter-state communications. The provisions of Article 21 of the CAT are similar.

73 See, e.g., CAT Optional Protocol, supra note 28, art. 21(h) (instructing parties to submit a report including a brief statement of the facts); ICCPR, supra note 6 , art. 41(h) (stating that the Committee shall limit its report to a brief statement of the facts).

74 Several of the main international human rights treaties include articles or optional protocols with this additional enforcement mechanism. See, e.g., CAT Optional Protocol, supra note 28, art. 22 (stating that no claim shall be heard unless competence of the committee is declared by the state); CEDAW Optional Protocol, supra note 27 (authorizing the state to hear the claims brought if it deems the committee competent); ICCPR First Optional Protocol, supra note 27 (allowing state to determine committee's competence to hear claims); CERD, supra note 6, art. 14 (authorizing the state to hear such claims only if it deems the committee competent).

75 For example, in Article 7, the CEDAW Optional Protocol permits the Committee to seek comments and reports on actions taken by states. 
compliance and issuing reports of its actions. ${ }^{76}$ Moreover, according to the website for the Office of the High Commissioner for Human Rights, as of August 2010, the procedures for interstate complaints had never been used. ${ }^{77}$

Although there is not an enormous difference between the latter two enforcement mechanisms in terms of the precision of their requirements or the power of the committees, I conclude that the individual complaint mechanism may be costlier for states for several reasons. First, states should expect more individual complaints than state complaints because individuals within a state are more likely than other states to actually know of the actual state's human rights practices. Second there are also more individuals in a state than there are other states. Finally, the evidence suggests that states are not inclined to use the interstate complaint procedure, a fact which later-ratifying states would know when considering the strength of that enforcement mechanism. By contrast, the various committees have received and considered individual complaints and have rendered decisions. Again, however, those decisions are not subject to appeal, and if the committee decides in favor of the individual, it cannot force a remedy: it is limited to inviting the state party to show how it has resolved the issue.

Under the Optional Protocol to the CAT, states may commit to a seemingly stronger enforcement mechanism. By that Optional Protocol, states bind themselves to recognize the competence of a Subcommittee on Prevention to regularly visit any place under its jurisdiction and control where persons are held in detention by the government or with its acquiescence. ${ }^{78}$ The visits are undertaken in an effort to strengthen, if necessary, the detainees' rights to be protected against torture and other cruel and inhumane punishment. ${ }^{79}$ In connection with the visits, parties agree to

76 See, e.g., CEDAW Optional Protocol, supra note 27, arts. 7, 12 (describing the committee's powers as essentially overseeing compliance and issuing reports on its actions); ICCPR First Optional Protocol, supra note 28, arts. 5, 6 (stating that the role of the committee shall not exceed reporting on its actions and monitoring compliance).

77 See Human Rights Treaty Bodies - Petitions, OfFICE OF THE UNITED NATIONS COMMISSIONER FOR HUMAN RIGHTS, http://www2.ohchr.org/english/bodies/ petitions/index.htm (last visited Jan. 23, 2012) (stating that although state parties are permitted to complain to the relevant treaty body about alleged violations by other states, no state has ever done so).

78 CAT Optional Protocol, supra note 28, arts. 4, 11.

79 Id. art. 4. 
provide all relevant information to the Subcommittee, as well as access to private interviews of detainees - without the presence of witnesses. ${ }^{80}$ Pursuant to Article 16, the Subcommittee is authorized to publish reports of its investigations, together with any comments the state party may wish to include. ${ }^{81}$ In the event the state party does not cooperate with the Subcommittee and does not authorize access to information and interviews, or refuses to take steps to improve a situation identified by the Subcommittee, the Subcommittee may-after the state party has had an opportunity to make its views known-make a public statement concerning the matter or publish a report about it. ${ }^{82}$

The committee with oversight of the CAT Optional Protocol, like the other committees, is generally limited at the conclusion of its investigation to encouraging compliance and making comments or reports. I suggest, though, that the enforcement mechanism associated with the CAT Optional Protocol is stronger than those described above because it requires states to allow an independent body onto sovereign territory and to grant access to citizenry or other prisoners under state control. While all states will not necessarily comply with that requirement, sidestepping the requirement is certainly not as easy as filing a pro forma report. Furthermore, neither the interstate nor individual complaint procedures purport to bind the state parties to allowing a committee to visit the territory and conduct its own investigation of the facts.

On the other hand, in none of the above instances have states delegated to an independent body the power to make legally binding decisions. Thus, even the strongest of these enforcement mechanisms giving committees powers to monitor compliance may not be very "strong." Of course, even if they are not "strong" enforcement mechanisms, they may still help prompt states to improve their respect for individual human rights. For example, the reports, decisions, and comments by the committees may shame states into improving their domestic policies and practices. Those reports, decisions, and comments can also be accessed by states, NGOs, and domestic civil society and similarly used by any of them to shame states into complying with international human rights norms. Regarding the level of the enforcement mechanisms

\footnotetext{
$80 I d$. arts. 12, 14.

81 Id. art. 16.

$82 \mathrm{Id}$.
} 
to which states bind themselves pursuant to the treaty's terms, however, the fact remains that the committees do not have legally binding adjudicatory power with resources to compel compliance and punish bad and noncompliant behavior.

Rather, of the fourteen treaties, articles, or protocols in this study, the ICC treaty can best be characterized as having relatively strong "hard law" enforcement mechanisms. Indeed, the ICC treaty is unlike any international human rights treaty that has gone before it. Pursuant to the terms and provisions of the Rome Statute, states have designated to an independent entity the authority to determine whether there is evidence to believe an individual or group committed one of the covered crimes within the territory of a State Party. In addition, they have delegated the power to determine whether the state which would otherwise have jurisdiction over the matter is itself either unwilling or unable to prosecute the wrongdoers. And, by committing to the treaty creating the ICC, states agree that such investigations may be commenced against the state's own nationals for the covered crimes of genocide, crimes against humanity, or war crimes, as long as those crimes were committed after the Court came into existence or after the state ratified the treaty, whichever is later. Furthermore, unlike the committees associated with the other international human rights treaties, the ICC does control resources that can be used to prevent abuses or to punish offenders.

For example, the ICC may issue arrest warrants to bring individuals or groups to stand trial for their crimes before judges at the ICC in The Hague. And, states and individuals have responded to the ICC's power of arrest. Some states have cooperated in bringing suspects to The Hague for trial. ${ }^{83}$ Other

83 Belgian authorities arrested the former Vice-President of the Democratic Republic of the Congo-who was the subject of a sealed arrest warrant-during his visit to the country. Agence France-Presse, Congo Ex-Official Is Held In Belgium on War Crimes Charges, N.Y. TIMES, May 25, 2008, http://www.nytimes.com/ 2008/05/25/world/africa/25congo.html?ref=africa. In November 2011, Ivory Coast authorities surrendered Laurent Gbagbo pursuant to an ICC arrest warrant in connection with an investigation into the situation in the Ivory Coast opened by the ICC wherein Mr. Gbagbo is charged with allegedly committing mass atrocities in the aftermath of the country's presidential elections in 2010. Press Release, Int'1 Criminal Court [ICC], New Suspect in the ICC's Custody: Laurent Gbagbo Arrived at the Detention Centre, ICC-CPI-20111130-PR747 (Nov. 30, 2011), available at http://www.icc-cpi.int/NR/exeres/4814FA54-AF2D-4EA3-8A899E809318D1D8.htm. 
suspects have voluntarily appeared in The Hague in order to avoid having warrants issued for their arrest. 84

Of course, notwithstanding these powers to effectuate arrests and prosecute those who commit mass atrocities, some suspects may initially escape justice. The ICC has informed the United Nations Security Council of the failure of ICC States Parties Djibouti, Chad, Kenya, and Malawi to execute on the ICC's warrant for the arrest of President Omar Bashir of Sudan during his visits to these countries. ${ }^{85}$ Nevertheless, the power delegated to the ICC is still of a legally binding nature. Suspects may be able to escape arrest by staying in-state, hiding, or visiting only friendly states (and suspects can always escape arrest in similar ways even under domestic criminal law systems where police forces can effectuate arrests). But, those suspects are not completely free to do as they please, as President Bashir no doubt knows. Malawi's new President, Joyce Banda, publicly announced in June 2012 that her country would not host an African Union summit if she was obligated to invite Bashir as head of an AU member state, noting how strained ties with key donors in the international community became after her predecessor allowed Bashir to visit.86

84 Press Release, ICC, As Darfur Rebel Commanders Surrender to the Court, ICC Prosecutor "welcomes compliance with the Court's decisions and with Resolution 1593 (2005) of the Security Council," ICC-OTP-20100616-PR548 (June 16, 2010), available at http://www.icc-cpi.int/menus/icc/situations \% 20 and $\% 20$ cases/situations/situation $\% 20$ icc $\% 200205 /$ related $\% 20$ cases / icc02050309/press\%20release/pr548 (addressing the arrival of two Darfur rebel commanders to answer charges and face prosecution for their conduct); Kenya: $Q$ $\mathcal{E}$ A on Pre-Trial Hearing in First ICC Case, Human Rights Watch (Aug. 30, 2011), http://www.hrw.org/news/2011/08/30/ kenya-qa-pre-trial-hearing-first-icccase (noting that six Kenyans charged with committing mass atrocities in the aftermath of the country's 2007 presidential elections voluntarily appeared in The Hague to face charges pursuant to a summons to appear).

85 Press Release, ICC, Pre-Trial Chamber I informs the United Nations Security Council and the Assembly of States Parties About Chad's Noncooperation in the Arrest and Surrender of Omar Al Bashir, ICC-CPI-20111213PR756 (Dec. 31, 2011), available at http://www.icc-cpi.int/menus/icc/ situations $\% 20$ and $\% 20$ cases/situations/situation $\% 20$ icc $\% 200205 /$ related $\%$ 20cases/icc02050109/press\%20releases/pre_trial\%20chamber\%20i\%20informs \% 20 the $\% 20$ united $\% 20$ nations $\% 20$ security $\% 20$ council $\% 20$ and $\% 20$ the $\% 20$ assembly $\%$ 20of \%20states \%20parties\%20a.

86 See Malawi Cancels AU Summit Hosting Over Sudan's Leader Invite, RADIO NETH. WORLDWIDE (June 8, 2012, 1:42 PM), http://www.rnw.nl/internationaljustice/article/malawi-cancels-au-summit-hosting-over-sudans-leader-invite ("Malawi's new president, Joyce Banda, said in May that she wanted Bashir to stay away from the $[\mathrm{AU}]$ summit . . . to avoid straining ties with key donors for her impoverished country."). 
Furthermore, although the fact of the arrest warrant may actually provoke some suspects to engage in additional abuses or repressive behavior in order to fight against the ICC's authority, in many ways this only demonstrates the strength of the ICC's enforcement mechanism. Accordingly, I argue that the enforcement mechanisms in the fourteen different treaties that are the subject of this study can be arranged from weakest to strongest as follows: (1) the state agrees to a self-reporting requirement; (2) the state recognizes committee competence to hear state complaints; (3) the state recognizes committee competence to hear individual complaints; (4) the state agrees to permit committee visits to its territory to engage in investigations; and (5) the state agrees to authorize an independent body to prosecute its government or citizenry for human rights crimes. Table 2 lists the fourteen treaties, articles, or protocols (together with the year they were available for ratification), and organizes them by their associated levels of enforcement mechanisms.

Table 2: Fourteen Human Rights Treaties and Levels of Enforcement Mechanisms

\begin{tabular}{|l|l|l|}
\hline \multicolumn{1}{|c|}{$\begin{array}{c}\text { Level of } \\
\text { Enforcement }\end{array}$} & \multicolumn{1}{|c|}{ Description of Mechanism } & \multicolumn{1}{c|}{ Human Rights Treaty } \\
\hline 1-weakest & State must file reports & $\begin{array}{l}\text { ICCPR (1966); ICESCR (1966); } \\
\text { CERD (1966); CEDAW (1980); } \\
\text { CAT (1984); CRC (1989) }\end{array}$ \\
\hline 2-weak & $\begin{array}{l}\text { States make complaints to } \\
\text { committee }\end{array}$ & $\begin{array}{l}\text { Article 41 ICCPR (1966); } \\
\text { Article 21 CAT (1984) }\end{array}$ \\
\hline 3-moderate & $\begin{array}{l}\text { Individuals file complaints } \\
\text { with committee }\end{array}$ & $\begin{array}{l}\text { Optional Protocol ICCPR } \\
\text { (1966); Article 14 CERD } \\
(1966) ; \text { Article 22 CAT (1984); } \\
\text { Optional Protocol CEDAW } \\
(1999)\end{array}$ \\
\hline 4-stronger & Committee may visit state & Optional Protocol CAT (2003) \\
\hline 5-strongest & $\begin{array}{l}\text { Independent prosecutor } \\
\text { investigations }\end{array}$ & ICC (1998) \\
\hline
\end{tabular}

\section{RESEARCH DESIGN}

This study tests the credible threat theory quantitatively and pits that theory against the credible commitment theory and the 
external pressures theories described in Section 3 above. According to the credible threat theory, states will be more likely to ratify international human rights treaties with relatively strong enforcement mechanisms if their rational and backward looking cost calculations suggest commitment will not result in a significant loss of sovereignty. ${ }^{87}$ If the theory is correct, the statistical evidence should show that states with poor human rights practices will be just as likely as states with good human rights practices to readily ratify international human rights treaties containing the weakest enforcement mechanisms. States with poorer records, however, should be much less likely to ratify treaties with stronger enforcement mechanisms that can be used to punish bad and noncompliant behavior. Regarding in particular the treaty creating the ICC, the evidence should show that states with poorer human rights practices-namely, the states that are least likely to be able to comply with treaty terms and avoid being subjected to the treaty's relatively strong enforcement mechanisms - will refuse to join the Court.

The predictions of the credible commitment and the external pressures theories are in stark contrast to those of the credible threat theory. Those theories predict that even where enforcement mechanisms are stronger, states that may not be able to readily comply with treaty terms will still ratify. ${ }^{88}$ According to the credible commitment theory, in fact, where enforcement mechanisms are strongest-as they are in the ICC treaty-states with poor records and that are also non-democracies will join the Court in order to signal to their domestic audiences their intention to be better in the future. According to pressure theories, even states with poor past and present human rights practices will commit to treaties with stronger enforcement mechanisms because they are directly or indirectly pressured to join in order to obtain some extra-treaty benefits such as increased aid or trade.

\subsection{Methodology}

I use event history analysis ${ }^{89}$ - specifically, a Cox proportionalhazards model - to test the explanatory power of the credible threat theory and to test it against the credible commitment and external pressures theories. Event history analysis is an

\footnotetext{
87 See supra Section 4.

88 See supra Sections 3.1.2.2.1, 3.2

89 Event history analysis is also called "survival" analysis.
} 
appropriate methodology to use to examine state commitment to the various international human rights treaties in this study because it allows the researcher to incorporate both constant and time-varying factors into the quantitative model. ${ }^{90}$ For example, the researcher can include in the model data that varies over time, such as a state's yearly human rights and democracy ratings. The researcher can also include data that does not vary year-to-year, such as whether the state follows a common law or civil law legal tradition.

Event history models test each state's "time until" the event of treaty ratification and what factors speed up or slow down that time line to commitment. I examine state commitment to each of the fourteen different treaties in this study using separate, but parallel, analyses. Appendix A lists the fourteen different treaties and shows the states that are parties to each.

\subsection{Dependent Variables}

The dependent variables in the study are the time to ratification of each of the fourteen different international human rights treaties. Ratification data on the fourteen different international human rights treaties were coded from the United Nations. The data is assembled at yearly intervals for more than 190 countries between 1966 and 2008. Countries existing at the time the treaty was adopted and available for ratification in that year are "at risk" of ratifying during that year. Countries established after the treaty was available for ratification enter the risk set upon independence-the year when they are eligible to ratify as a sovereign state. Countries at risk are given a value of 0 until such time as they ratify the instrument in question. At the time of ratification-when the event happens-countries are assigned a value of 1 . Countries that did not ratify by 2008, when the observation period here ends, are right-censored since the event for them never happened, but can still happen.

\subsection{The Main Explanatory Variable: Level of Human Rights Practices}

While each treaty does have its own terms and particular rights that it is designed to protect, all have in common that they are

90 For a comprehensive description of event history analysis, see, for example, PAUL D. ALLISON, EVENT HISTORY ANALYSIS: REGRESSION FOR LONGitudinal Event Data (1984); Event History AnAlysis With Stata (HansPeter Blossfeld et al. eds., 2007). 
designed to require states and their leaders to promote better domestic human rights practices and protect against and punish any human rights abuses. Therefore, in order to consistently test commitment across the various treaties, I use one main explanatory variable to measure the state's ability to comply with treaty terms. In this case, that measure is the level of the state's human rights practices. Since the treaties in this study by their terms all require states to adhere to good human rights practices, compliance should be easiest and less costly for those states with policies and practices that are consistent with treaty terms. By contrast, states with bad past and present human rights practices should calculate that compliance would be difficult and also potentially quite costly if the treaty has relatively strong enforcement mechanisms.

To measure a state's level of human rights practices, I use the Political Terror Scale, which is a generally-recognized human rights measure obtained from human rights reports issued by Amnesty International and the U.S. Department of State. The reports assign country scores by considering the presence of government practices that include murder, torture, forced disappearances, and political imprisonment. The scale ranges from 1 to 5, where 1 corresponds with torture and political imprisonments occurring only rarely and the country generally protecting human rights. ${ }^{91}$ Thus, states assigned a 1 will have the best human rights practices using this scale, and states assigned a 5 will have the worst practices. When possible, I average the two scores reported. ${ }^{92}$ Data on these human rights practices are available beginning in 1976 and are reported from each year

91 I chose not to include in my model a measure of "recent civil wars" as did Simmons and Danner because, as previously noted, I do not believe that measure best captures the concept of the level of a state's human rights practices or the likelihood that it will commit a mass atrocity. See supra note 53. On the other hand, the political terror data on human rights practices directly measures a state's tendency to commit the kinds of human rights violations that cause it to run afoul of the terms of the various international human rights treaties described above, as well as subject the state's leaders and citizens to an ICC prosecution.

92 Averaging the scores should help mitigate any bias from using only scores based on Amnesty International or the U.S. State Department reports. In any event, scholars have found that over time, the similarity between the reports of the two entities has increased. See Steven C. Poe et al., Repression of the Human Right to Personal Integrity Revisited: A Global Cross-National Study Covering the Years 1976-1993, 43 INT'L STUD. Q. 291, 301-02 (1999) (arguing that selection bias of Amnesty International and U.S. Department of State personal integrity abuse measures can be "addressed by substitution" and that these measures eventually converge to be "virtually identical"). 
thereafter until 2008. Similar to Cole, ${ }^{93}$ for the period between 1966 and 1976 (a time period relevant to the examination of several of the treaties), I extrapolate missing data points using a state's median score over the period from 1976 to 1984 if data is available. ${ }^{94}$ Again, because each of the treaties being tested is designed to ensure that states promote better human rights practices and protect against, and punish, human rights abuses, the data should adequately measure a state's tendency to have in place policies and practices that would enable it to comply with these treaties.

\subsection{Control Variables}

I also include several control variables in the model to account for the various other theories that scholars have advanced to explain state commitment to international human rights treaties (outlined in Section 3 above). I describe each of these control variables briefly below. Appendix B describes in more detail the nature and source of the data used to measure the control variables.

93 See Cole, supra note 22, at 480 ("Missing data points between 1966 and 1974 are extrapolated from a country's median score over the period 1975-1999.").

94 I considered using the physical integrity rights measure reported in the Cingranelli-Richards Human Rights Dataset. That measure also ranks a state's respect for human rights based on data from Amnesty International and U.S. State Department reports addressing tortures, extrajudicial killings, political imprisonments, and disappearances. The physical integrity rating is specified on a 0 to 8 scale, with 8 representing full governmental respect for physical rights. However, the Cingranelli-Richards data is only available beginning in 1981, making it not as comprehensive for these purposes as the data available from the Political Terror Scale, which begins in 1976. Compare The CIRI Human Rights Data Project, CIRI HuMAN RIGHTS DATA PROJECT, http:// ciri.binghamton.edu/index.asp (last revised Jan. 14 2012) with The Political Terror Scale Online, POLITICAL TERROR SCALE, www.politicalterrorscale.org/ptsdata.php (last updated Nov. 3, 2012). Furthermore, the other studies that compare ratification decisions across international human rights treaties beginning in 1966 also use the Political Terror Scale to measure a state's human rights practices. See Wotipka \& Tsutsui, supra note 22, at 743 (describing variables used in analyzing international human rights treaties from 1965 to 2001); Cole, supra note 22, at 480 ("Using data collected from annual human rights reports issued by Amnesty International and the U.S. Department of State, countries are assigned a score of 1 to 5 on an ordinal scale... ."). Thus, a comparison to the results of those studies is better facilitated by using the same measure here. 


\subsubsection{The Rationalist View}

To test the idea that democracies are more likely than autocracies to ratify international human rights treaties, I include a measure of democracy taken from the Polity IV Project.

I use a state's gross domestic product ("GDP") per capita as a measure of economic development to test the hypothesis that more economically developed states are more likely than less developed states to join international human rights treaties. GDP per capita is a standard control variable in cross-national research and is used as a proxy for a country's general level of economic development. ${ }^{95}$

To measure the political costs associated with a state's domestic legislative treaty ratification process, I use Simmons' data, which codes ratification processes using a four-category scale according to the difficulty of the processes. ${ }^{96}$

To test the future domestic uncertainty costs theory and the idea that states following a common law tradition are less likely to ratify international human rights institutions than those following a civil law tradition, I include data on whether a state follows a common law legal tradition.

Finally, I include a control variable to measure the new democracy, democratic "lock-in" theory advanced by Andrew Moravcsik using a dummy variable derived from the Polity IV democracy measure.

\subsubsection{The External Pressures View}

Regarding external pressures that may influence state ratification behavior, I first include a measure to account for the idea that less developed states may ratify treaties so as to receive extra-treaty benefits from more powerful and wealthier nations.

95 See SIMMONS, supra note 22, at 83-84 tbl.3.1 (using log of GDP per capita and $\log$ of GDP by size as explanatory variables in evaluating ratification of human rights treaties); Cole, supra note 22, at 480 ("Gross domestic product (GDP) per capita, a standard control variable in cross-national research, proxies a country's general level of economic development."); Wotipka \& Tsutsui, supra note 22, at 737 (averring that "level of economic development is a key factor shaping governments' decision to ratify treaties").

96 See SimMONS, supra note 22, app. I at 383 (defining the ratification process according to four categories capturing the degree of political difficulty in the formal process of ratification including (1) ratification by an individual chief executive or cabinet decision, (2) a rule of informing the legislative body of signed treaties, (3) majority consent of one legislative body, and (4) a supermajority in one legislative body or a majority in two legislative bodies). 
Like Simmons, I measure this concept using net official development assistance and official aid ("ODA"). ${ }^{97}$ ODA consists of the loans and grants made to developing countries.

Last, I measure the concept concerning regional influence by looking at regional density of the ratification of the various treaties, articles, and optional protocols. Regional density computes ratification by countries in the same region (using seven World Bank categories) up to the previous year. ${ }^{98}$

Table 3 provides the summary statistics for the independent variables described above and used to test commitment to all fourteen international human rights treaties, articles, or optional protocols included in this study.

Table 3: Summary Statistics for Common Independent Variables

\begin{tabular}{|l|l|l|l|l|l|}
\hline \multicolumn{1}{|c|}{ Variable } & Observations & Mean & $\begin{array}{c}\text { Standard } \\
\text { Deviation }\end{array}$ & $\begin{array}{c}\text { Min. } \\
\text { Value }\end{array}$ & $\begin{array}{c}\text { Max. } \\
\text { Value }\end{array}$ \\
\hline $\begin{array}{l}\text { Level of Human } \\
\text { Rights }\end{array}$ & 6597 & 2.39 & 1.09 & 1 & 5 \\
\hline Level of Democracy & 6498 & 4 & 4.18 & 0 & 10 \\
\hline $\begin{array}{l}\text { Level of Economic } \\
\text { Development }\end{array}$ & 7015 & 7.52 & 1.56 & 4.13 & 11.26 \\
\hline $\begin{array}{l}\text { Difficulty of } \\
\text { Domestic Treaty } \\
\text { Ratification Process }\end{array}$ & 4834 & 1.57 & .65 & 1 & 3 \\
\hline $\begin{array}{l}\text { Common Law State } \\
\text { or Not }\end{array}$ & 8481 & .34 & .47 & 0 & 1 \\
\hline $\begin{array}{l}\text { Transitioning } \\
\text { Democracy or Not }\end{array}$ & 6794 & .17 & .38 & 0 & 1 \\
\hline $\begin{array}{l}\text { Level of Aid or } \\
\text { Assistance }\end{array}$ & 7059 & .09 & .16 & -.03 & 2.68 \\
\hline
\end{tabular}

97 See id. app. I at 385 (defining ODA using World Bank data measuring official development assistance and official aid, denominated in U.S. dollars, as a share of GDP).

98 The seven World Bank regions are: Sub-Saharan Africa; East Asia/Oceania; Eastern Europe/Central Asia; Latin America/Caribbean; Middle East/North Africa; South Asia; and the West (Western Europe, Australia, Canada, New Zealand, and the United States). See Countries and Regions, WORLD BANK, http:/ / web.worldbank.org/WBSITE/EXTERNAL/COUNTRIES/0,, pagePK:180619 theSitePK:136917,00.html. 


\section{EMPIRICAL ANALYSES AND DISCUSSION OF RESULTS}

An examination of state ratification patterns provides contextual background helpful to understanding the results of the event history analysis and also provides preliminary support for the idea that states view strong enforcement mechanisms as a credible threat. Table 4 contains a list of the fourteen different international human rights treaties that are the subject of this study and shows that states with worse human rights practices are almost just as likely as states with better human rights practices to ratify international human rights treaties with the weakest enforcement mechanisms. However, where enforcement mechanisms are stronger, states with worse human rights practices are much more likely to avoid commitment.

Table 4: Ratification of the Fourteen Different Treaties Based on Human Rights Ratings ${ }^{99}$

\begin{tabular}{|l|l|l|l|}
\hline \multicolumn{1}{|c|}{ Treaty } & $\begin{array}{c}\text { Total \# } \\
\text { Ratified }\end{array}$ & $\begin{array}{c}\text { \# Ratified with Better } \\
\text { Human Rights }\end{array}$ & $\begin{array}{c}\text { \# Ratified with Worse } \\
\text { Human Rights }\end{array}$ \\
\hline ICCPR & 157 & 83 & 74 \\
\hline ICESCR & 154 & 80 & 74 \\
\hline CERD & 162 & 86 & 76 \\
\hline CEDAW & 171 & 95 & 76 \\
\hline CAT & 139 & 73 & 66 \\
\hline CRC & 174 & 95 & 79 \\
\hline ICCPR Art. 41 & 47 & 31 & 16 \\
\hline CAT Art. 21 & 56 & 39 & 17 \\
\hline ICCPR Optional & 96 & 60 & 36 \\
\hline CERD Art. 14 & 47 & 31 & 16 \\
\hline CAT Art. 22 & 60 & 37 & 23 \\
\hline CEDAW Optional & 89 & 57 & 32 \\
\hline CAT Optional & 41 & 29 & 12 \\
\hline ICC & 98 & 66 & 32 \\
\hline
\end{tabular}

99 I classified states with average human rights ratings of 2.5 and below during the relevant time periods at which the various treaties could be ratified as having better human rights practices. I classified states with average human rights ratings above 2.5 during the relevant time periods as having poorer human rights practices.

100 I obtained the total number of ratifying states from the data which ends in 2008. For each treaty, the total possible number of states that could have ratified was 178 since those were the states for which human rights data was available. 
In fact, where the treaties contain only the weakest selfreporting mechanisms (the first six treaties listed), Table 4 shows that the number of states with better and worse ratings ratifying the treaty is close to equal. By contrast, as enforcement mechanisms strengthen, states with poorer human rights practices tend to account for only about thirty percent of the ratifying population. The figure below illustrates these ratification patterns.

\section{Figure 1: Ratification of the Fourteen Different Treaties Based on Average Human Rights Ratings}

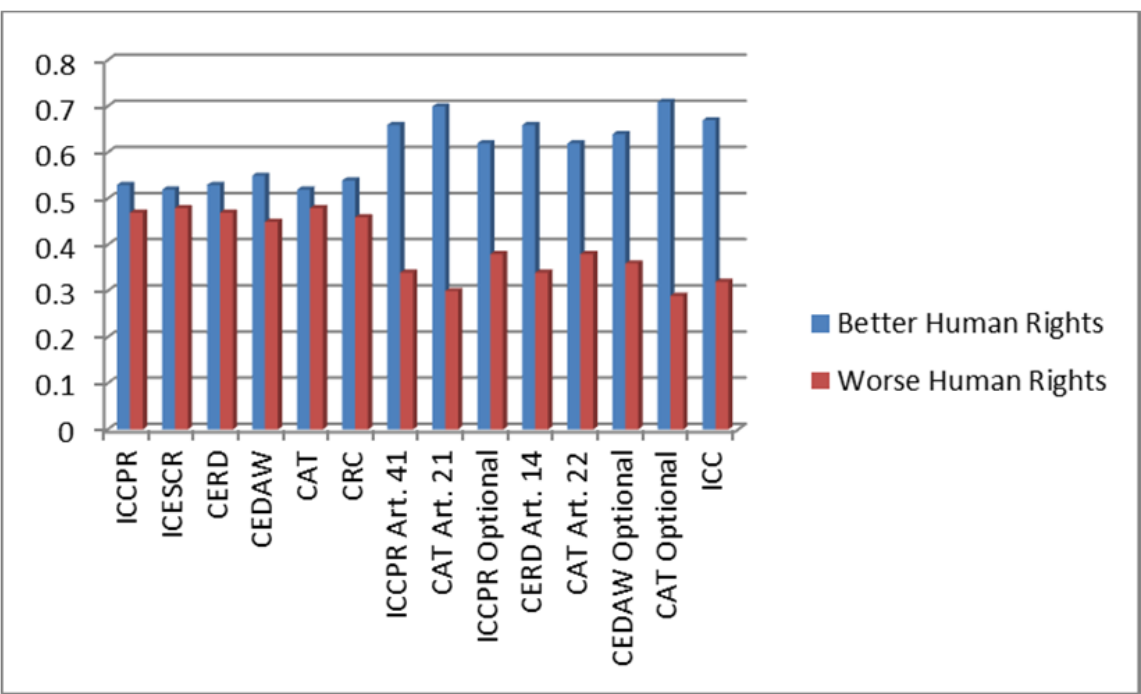

Examining the ratification patterns of states with the poorest human rights ratings ${ }^{101}$ provides additional support for the credible threat theory. Table 5 shows ratification behavior as it relates to the six main international human rights treaties and the ICC treaty. The evidence indicates that states with the poorest human rights practices readily and regularly commit to international human rights treaties with the weakest enforcement mechanisms. However, states with the poorest practices less readily commit to the ICC treaty.

101 States with the poorest ratings are those that consistently averaged above 2.5 on the political terror scale (which ranges from 1 to 5 with 5 representing the worst practices) during each of the five time periods relevant to the seven treaties. Those time periods are 1965-2008 (ICCPR, ICESCR, and CERD); 1979-2008 (CEDAW); 1983-2008 (CAT); 1988-2008 (CRC); and 1997-2008 (ICC). 
Table 5: Poorest Human Rights Countries and Ratifications

\begin{tabular}{|c|c|c|c|c|c|c|c|}
\hline Country & ICC & CCPR & CESCR & CERD & CEDAW & CAT & CRC \\
\hline Afghanistan & 2003 & 1983 & 1983 & 1983 & 2003 & 1987 & 1994 \\
\hline Albania & 2003 & 1991 & 1991 & 1994 & 1994 & 1994 & 1992 \\
\hline Algeria & - & 1989 & 1989 & 1972 & 1996 & 1989 & 1993 \\
\hline Andorra & 2001 & 2006 & - & 2006 & 1997 & 2006 & 1996 \\
\hline Bangladesh & 2010 & 2000 & 1998 & 1979 & 1984 & 1998 & 1990 \\
\hline Brazil & 2002 & 1992 & 1992 & 1968 & 1984 & 1989 & 1990 \\
\hline Burundi & 2004 & 1990 & 1990 & 1977 & 1992 & 1993 & 1990 \\
\hline Cambodia & 2002 & 1992 & 1992 & 1983 & 1992 & 1992 & 1992 \\
\hline Cameroon & - & 1984 & 1984 & 1970 & 1994 & 1986 & 1993 \\
\hline $\begin{array}{l}\text { Central Afr. } \\
\text { Rep. }\end{array}$ & 2001 & 1981 & 1981 & 1971 & 1991 & - & 1992 \\
\hline Chad & 2006 & 1995 & 1995 & 1977 & 1995 & 1995 & 1990 \\
\hline China & - & - & 2001 & 1981 & 1980 & 1988 & 1992 \\
\hline Colombia & 2002 & 1969 & 1969 & 1981 & 1982 & 1987 & 1991 \\
\hline Congo (Brazza) & 2004 & 1983 & 1983 & 1988 & 1982 & 2003 & 1993 \\
\hline DRC (Kinshasa) & 2002 & 1976 & 1976 & 1976 & 1986 & 1996 & 1990 \\
\hline Cuba & - & - & - & 1972 & 1980 & 1995 & 1991 \\
\hline Egypt & - & 1982 & 1982 & 1967 & 1981 & 1986 & 1990 \\
\hline $\begin{array}{l}\text { Equatorial } \\
\text { Guinea }\end{array}$ & - & 1987 & 1987 & 2002 & 1984 & 2002 & 1992 \\
\hline Eritrea & - & 2002 & 2001 & 2001 & 1995 & - & 1994 \\
\hline Ethiopia & - & 1993 & 1993 & 1976 & 1981 & 1994 & 1991 \\
\hline Georgia & 2003 & 1994 & 1994 & 1999 & 1994 & 1994 & 1994 \\
\hline Guatemala & - & 1992 & 1988 & 1983 & 1982 & 1990 & 1990 \\
\hline Guinea & 2003 & 1978 & 1978 & 1977 & 1982 & 1989 & 1990 \\
\hline Haiti & - & 1991 & - & 1972 & 1981 & - & 1995 \\
\hline Honduras & 2002 & 1997 & 1981 & 2002 & 1983 & 1996 & 1990 \\
\hline India & - & 1979 & 1979 & 1968 & 1993 & - & 1992 \\
\hline Indonesia & - & 2006 & 2006 & 1999 & 1984 & 1998 & 1990 \\
\hline Iran & - & 1975 & 1975 & 1968 & - & - & 1994 \\
\hline Iraq & - & 1971 & 1971 & 1970 & 1986 & - & 1994 \\
\hline Israel & - & 1991 & 1991 & 1979 & 1991 & 1991 & 1991 \\
\hline Kenya & 2005 & 1972 & 1972 & 2001 & 1984 & 1997 & 1990 \\
\hline North Korea & - & 1981 & 1981 & - & 2001 & - & 1990 \\
\hline Lebanon & - & 1972 & 1972 & 1971 & 1997 & 2000 & 1991 \\
\hline Liberia & 2004 & 2004 & 2004 & 1976 & 1984 & 2004 & 1993 \\
\hline
\end{tabular}




\begin{tabular}{|l|l|l|l|l|l|l|l|}
\hline Libya & - & 1970 & 1970 & 1968 & 1989 & 1989 & 1993 \\
\hline Morocco & - & 1979 & 1979 & 1970 & 1993 & 1993 & 1993 \\
\hline Mozambique & - & 1993 & - & 1983 & 1997 & 1999 & 1994 \\
\hline Mexico & 2005 & 1981 & 1981 & 1975 & 1981 & 1986 & 1990 \\
\hline Myanmar & - & - & - & - & 1997 & - & 1991 \\
\hline Nigeria & 2001 & 1993 & 1993 & 1967 & 1985 & 2001 & 1991 \\
\hline Pakistan & - & - & 2009 & 1966 & 1996 & - & 1990 \\
\hline $\begin{array}{l}\text { Papua New } \\
\text { Guinea }\end{array}$ & - & 2008 & 2008 & 1982 & 1995 & - & 1993 \\
\hline Paraguay & 2001 & 1992 & 1992 & 2003 & 1987 & 1990 & 1990 \\
\hline Peru & 2001 & 1978 & 1978 & 1971 & 1982 & 1988 & 1990 \\
\hline Philippines & - & 1986 & 1974 & 1967 & 1981 & 1986 & 1990 \\
\hline Russia & - & 1973 & 1973 & 1969 & 1981 & 1987 & 1990 \\
\hline Rwanda & - & 1975 & 1975 & 1975 & 1981 & 2008 & 1991 \\
\hline Saudi Arabia & - & - & - & 1997 & 2000 & 1997 & 1996 \\
\hline Sierra Leone & 2000 & 1996 & 1996 & 1967 & 1988 & 2001 & 1990 \\
\hline Somalia & - & 1990 & 1990 & 1975 & - & 1990 & - \\
\hline South Africa & 2000 & 1998 & - & 1998 & 1995 & 1998 & 1995 \\
\hline Sri Lanka & - & 1980 & 1980 & 1982 & 1981 & 1994 & 1991 \\
\hline Sudan & - & 1986 & 1986 & 1977 & - & - & 1990 \\
\hline Syria & - & 1969 & 1969 & 1969 & 2003 & 2004 & 1993 \\
\hline Tajikistan & 2000 & 1999 & 1991 & 1995 & 1993 & 1995 & 1993 \\
\hline Thailand & - & 1996 & 1999 & 2003 & 1985 & 2007 & 1992 \\
\hline Togo & - & 1984 & 1984 & 1972 & 1983 & 1987 & 1990 \\
\hline Tunisia & - & 1969 & 1969 & 1967 & 1985 & 1988 & 1992 \\
\hline Turkey & - & 2003 & 2003 & 2002 & 1985 & 1988 & 1995 \\
\hline Uganda & 2002 & 1995 & 1987 & 1980 & 1985 & 1986 & 1990 \\
\hline Ukraine & - & 1973 & 1973 & 1969 & 1981 & 1987 & 1991 \\
\hline Uzbekistan & - & 1995 & 1995 & 1995 & 1995 & 1995 & 1994 \\
\hline Venezuela & 2000 & 1978 & 1978 & 1967 & 1983 & 1991 & 1990 \\
\hline Yemen & - & 1987 & 1987 & 1972 & 1984 & 1991 & 1991 \\
\hline Zambia & 2002 & 1984 & 1984 & 1972 & 1985 & 1998 & 1991 \\
\hline Zimbabwe & - & 1991 & 1991 & 1991 & 1991 & - & 1990 \\
\hline & & & & & & & \\
\hline
\end{tabular}

Specifically, of the sixty-six countries with the poorest human rights ratings, sixty-five (all except Myanmar) ratified at least four of the six main international human rights treaties. All but eighteen ratified all six treaties. By contrast, thirty-nine of the sixty-six countries with the poorest ratings did not ratify the ICC treaty. Among the thirty-nine countries that did not ratify the ICC 
treaty, some twenty-three nevertheless ratified all six main international human rights treaties - the treaties with the weakest enforcement mechanisms. ${ }^{102}$

In sum, an examination of state ratification patterns provides support for the explanatory power of the credible threat theory. The evidence shows that for the most part, states with poorer human rights practices are regularly joining treaties with the weakest enforcement mechanisms. They are doing so even though their past and present human rights ratings indicate they likely cannot comply with treaty terms and promote better domestic human rights practices and protect against, and punish, abuses. Of course, by committing to these treaties with the weakest enforcement mechanisms, states likely know they cannot be punished for bad and noncompliant behavior. On the other hand, those same states are less regularly committing to treaties with stronger enforcement mechanisms, including the treaty creating the ICC. Contrary to the predictions of the credible commitment theory and the external pressures theories, states with worse practices do not seem to be committing overwhelmingly to treaties with stronger enforcement mechanisms that can be used to punish bad and noncompliant behavior. Instead, consistent with the credible threat theory, it seems that these states with poor practices are for the most part looking backwards and rationally calculating compliance costs before committing to treaties with which they cannot presently comply and that have enforcement mechanisms that can be used to hold them to their commitment.

The results of event history analysis also provide support for the idea that states view strong enforcement mechanisms as a credible threat and more readily commit to treaties with stronger enforcement mechanisms only where they are also willing and able to comply with treaty terms. Tables $6,7,8,9$, and 10 present the results from event history analysis for ratification of the various international human rights treaties. The separate but parallel analyses for the fourteen different international human rights treaties are shown based on their associated level of enforcement mechanisms. The results are reported as hazard ratios, which

102 Results were consistent for countries that scored even higher on the political terror scale. For countries that consistently averaged above 2.8 during all relevant time periods, twenty-nine of forty-three did not ratify the ICC. However, all but Myanmar ratified at least four of the six main international human rights treaties. And, seventeen of the twenty-nine that did not ratify the ICC treaty nevertheless ratified all six of the main treaties. 
indicate the particular factor's proportionate influence on the decision to ratify. Numbers greater than one indicate an increase in the hazard rate of ratification. Numbers less than one indicate a decrease in the hazard rate.

As Table 6 shows, where enforcement mechanisms are weakest and require only self-reporting, the results show no statistically significant correlation between a state's level of human rights practices and state ratification behavior. This finding is consistent with Cole's regarding state commitment to the ICCPR and ICESCR - the two main international human rights treaties he examined in his study testing state ratification behavior. ${ }^{103}$ Indeed, where enforcement mechanisms are weakest, the primary explanatory variable - a state's level of human rights practices - is not a significant predictor of ratification in the tests for any of these treaties. Thus, just as the evidence depicted in Table 4 indicates, states with poorer human rights practices seem to be just as likely as states with better practices to join international human rights treaties with weak enforcement mechanisms that cannot be used to punish bad and noncompliant behavior. For states with better practices, of course, whether enforcement mechanisms are weak may not be a deciding factor in ratification calculations since the state already has policies and practices in place that should not cause it to run afoul of treaty terms. But, states with worse practices can decide to commit to treaties with these weakest enforcement mechanisms even if they have no ability or intent to comply with treaty terms or better their practices because the treaty is too toothless to compel compliance.

103 See Cole, supra note 22, at 483 (analyzing the correlation of various factors with the likelihood of ratification of the ICCPR and ICESCR and finding no significant trend with respect to human rights practices). On the other hand, Wotipka and Tsutsui found that states' human rights practices were significantly and negatively related to their tendency to ratify the six main human rights treaties. See Wotipka \& Tsutsui, supra note 22, at 744-47 ("The effects of . . . human rights practice indicate[s] that . . . rights-violating governments are more likely to ratify human rights treaties in a given year, all else being equal."). However, those scholars did not separately test commitment to each of the human rights treaties as I do-and as Cole did for the two main treaties in his study. Rather, in Wotipka and Tsutsui's study the event examined was whether a state ratified any one of seven human rights treaties in a given year between 1965 and 2001. See id., at 739. 
Table 6: Level 1 Enforcement Mechanisms: State Reporting

\begin{tabular}{|l|l|l|l|l|l|l|}
\hline \multicolumn{1}{|c|}{$\begin{array}{c}\text { Explanatory } \\
\text { Variables }\end{array}$} & \multicolumn{5}{c|}{ Hazard Ratios } \\
\hline & CCPR & CESCR & CERD & CEDAW & CAT & CRC \\
\hline $\begin{array}{l}\text { Level of Human } \\
\text { Rights }\end{array}$ & 1.024 & .903 & .827 & 1.066 & .917 & .961 \\
\hline $\begin{array}{l}\text { Level of } \\
\text { Democracy }\end{array}$ & $1.20^{* * *}$ & $1.20^{* * *}$ & 1.030 & $1.107^{* *}$ & 1.043 & $1.109^{* *}$ \\
\hline $\begin{array}{l}\text { Level of Economic } \\
\text { Development }\end{array}$ & $.737^{* *}$ & $.680^{* * *}$ & .938 & .773 & 1.119 & $.620^{* * *}$ \\
\hline $\begin{array}{l}\text { Difficulty of } \\
\text { Ratification } \\
\text { Process }\end{array}$ & .792 & $.489^{* * *}$ & $.547^{* *}$ & .837 & .849 & .702 \\
\hline $\begin{array}{l}\text { Common Law or } \\
\text { Not }\end{array}$ & .603 & $.287^{* * *}$ & .576 & $.412^{* * *}$ & $.340^{* * *}$ & $.438^{* * *}$ \\
\hline $\begin{array}{l}\text { Transitioning } \\
\text { Democracy or Not }\end{array}$ & .389 & $.296^{* *}$ & 1.079 & .892 & .986 & .917 \\
\hline Level of Aid & .132 & .042 & .178 & $.023^{* *}$ & .096 & .405 \\
\hline $\begin{array}{l}\text { Regional } \\
\text { Ratifications }\end{array}$ & $13.0^{* * *}$ & $7.93^{* * *}$ & $5.682^{* *}$ & 1.28 & $6.35^{* * *}$ & .647 \\
\hline \# of Countries & 74 & 73 & 57 & 69 & 107 & 82 \\
\hline \# of Ratifications & 57 & 55 & 51 & 65 & 80 & 81 \\
\hline \# of Observations & 1051 & 1056 & 610 & 491 & 1003 & 213 \\
\hline
\end{tabular}

${ }^{* *}$ significant at $.05 ;{ }^{* * *}$ significant at .01

In fact, state ratification behavior as to these six main international human rights treaties appears somewhat indiscriminate since the results indicate no factor is consistently correlated with ratification. Of the factors that are significant predictors of ratification behavior for more than one of the six main treaties, the hazard ratios for the democracy, difficulty of ratification process, common law, and regional indicators are in the predicted direction. Democracies are more likely than autocracies to quickly ratify each of the ICCPR, ICESCR, CEDAW, and CRC. States with more difficult ratification procedures are less likely to ratify the ICESCR and CERD. Common law states are less likely to commit to the ICESCR, CEDAW, CAT, and CRC. Regional ratification patterns positively influence ratification of the ICCPR, ICESCR, CERD, and CAT. But, while these various factors did influence commitment in some cases, their influence was not in 
any way uniform across these treaties with the same enforcement mechanism. Only ratification of the ICESCR is significantly influenced by all four of these factors.

In sum, ratification of the main treaties does not seem to be influenced by any one factor, and the main compliance cost variable-a state's level of human rights practices-is not a significant predictor of ratification behavior in these cases where enforcement mechanisms are weakest. Instead, and as shown in Table 4, states with poorer human rights practices seem to be readily and regularly joining these treaties with the weakest enforcement mechanisms despite the fact that they may be unable or unwilling to comply with the treaty's terms and goals. But, since the treaty's enforcement mechanisms are too weak to punish bad and noncompliant behavior, these "bad" states can join with no risk to their sovereignty and as window dressing only. ${ }^{104}$

The results of the tests of the treaties grouped in Enforcement Level 2 (interstate complaints) also lend support to the credible threat theory. The results reported in Table 7 show that better human rights practices did not significantly and positively predict state ratification of either Article 41 of the ICCPR or Article 21 of the CAT. In those models, only democracy and regional ratifications are significant and then only with respect to ratification of CAT Article 21. Otherwise, none of the other indicators are significant predictors of ratification behavior, suggesting that state decisions to ratify may not be based on a rational costs and benefits analysis when enforcement mechanisms are still relatively weak. Indeed, the treaty terms associated with the treaties grouped in Enforcement Level 2 make clear that committee power will be limited to trying to negotiate a resolution to any interstate complaints. Moreover, it seems the interstate complaint practice is not really used in any event - a fact that states ratifying the treaty likely knew when they decided to bind themselves to this mechanism. For example, twenty-six of the forty-eight states that have ratified Article 41 of the ICCPR did not do so until 1990 or after (even though many could have ratified

104 See Hafner-Burton \& Tsutsui, supra note 5, at 1378 (noting that mechanisms for treaty enforcement are often weak, which encourages ratification because states obtain the benefit of having signed onto the treaty while at the same time might avoid the consequences of any non-compliant behavior). 
beginning in 1966)-by which time states likely realized the provision for interstate complaints was not being invoked. 105

Table 7: Level 2 Enforcement Mechanisms: Interstate Complaints

\begin{tabular}{|l|l|l|}
\hline \multicolumn{1}{|c|}{ Explanatory Variables } & \multicolumn{2}{c|}{ Hazard Ratios } \\
\hline & Art. 41 ICCPR & Art. 21 CAT \\
\hline Level of Human Rights & 1.042 & 1.008 \\
\hline Level of Democracy & 1.155 & $1.170^{* *}$ \\
\hline Level of Economic Development & 1.245 & 1.585 \\
\hline Difficulty of Ratification Process & .653 & .734 \\
\hline Common Law or Not & 1.632 & .473 \\
\hline Transitioning Democracy or Not & .707 & 1.220 \\
\hline Level of Aid & .789 & .120 \\
\hline Regional Ratifications & 14.775 & $8.368^{* *}$ \\
\hline \# of Countries & 121 & 129 \\
\hline \# of Ratifications & 18 & 34 \\
\hline \# of Observations & 2594 & 1910 \\
\hline
\end{tabular}

${ }^{* *}$ significant at $.05 ;{ }^{* * *}$ significant at .01

In short, there is scant evidence that the costs of noncompliance drive state decisions to commit to international human rights treaties with weak enforcement mechanisms. The measure for human rights practices was not significant in any of the models testing state ratification of treaties categorized as having Level 1 and Level 2 enforcement mechanisms. Furthermore, the evidence shows that democracies were more likely to ratify only some of the eight treaties grouped in Levels 1 and 2. Moreover, other factors also influenced treaty ratification in some cases, and in some cases those factors predicted ratification in ways that were contrary to theory.

Conversely, where the enforcement mechanisms are strongest, the empirical evidence suggests states engage in rational backward looking calculations and consider compliance costs and their level of human rights practices when making commitment decisions. As Table 8 shows, a state's level of human rights practices is a highly significant predictor of ICC ratification, and states with the worst human rights practices are much less likely to join the ICC. The

105 Thirty-four of the sixty states that have ratified Article 21 of the CAT similarly did not do so until 1990 or after. 
hazard ratio of .523 indicates that states are about $50 \%$ less likely to join the ICC with each unit decrease in their human rights practices. ${ }^{106}$ The democracy indicator of compliance is also significant for ICC treaty ratification, a fact which is consistent with the credible threat theory since democracies also tend to follow the rule of law, limit government power, and have the types of policies and practices enabling them to comply with international human rights treaties. With each unit improvement in its democracy rating, a state is about $20 \%$ more likely to ratify the ICC. These findings all support the credible threat theory: where enforcement mechanisms are strongest, states most able to comply with the ICC treaty requirements are also the most likely to ratify. Those less able to comply-namely, those with the worst human rights practices and non-democracies - are less likely to ratify.

Table 8: Level 5 Enforcement Mechanism: Independent Prosecutor

\begin{tabular}{|l|l|}
\hline \multicolumn{1}{|c|}{ Explanatory Variables } & \multicolumn{1}{c|}{ Hazard Ratios } \\
\hline & International Criminal Court \\
\hline Level of Human Rights & $.523^{* * *}$ \\
\hline Level of Democracy & $1.230^{* * *}$ \\
\hline Level of Economic Development & $.743^{* *}$ \\
\hline Difficulty of Ratification Process & 1.127 \\
\hline Common Law or Not & .939 \\
\hline Transitioning Democracy or Not & .673 \\
\hline Level of Aid & .134 \\
\hline Regional Ratifications & $7.389^{* *}$ \\
\hline \# of Countries & 135 \\
\hline \# of Ratifications & 74 \\
\hline \# of Observations & 848 \\
\hline
\end{tabular}

${ }^{* *}$ significant at $.05 ;{ }^{* * *}$ significant at .01

106 As a robustness check, I also ran the Level 5 and Level 1 ratification models using the Cingranelli-Richards measure for human rights practices. The results similarly showed that states with better human rights practices were significantly more likely than states with poor practices to commit to the ICC (Level 5). In the models testing ratification of the human rights treaties with the weakest enforcement mechanisms (Level 1), this measure of a state's human rights practices (like the Political Terror scale measure) was not a significant predictor of state commitment. 
Accordingly, these findings regarding ICC commitment lend support to the credible threat theory, but at the same time discredit the explanatory power of the credible commitment theory and the external pressures theories. In the case of the ICC, where enforcement mechanisms are strongest, the evidence does not suggest that non-democratic states or states with poor practices are more likely to bind themselves to a treaty with which they cannot, or will not, comply because they either want to tie their hands to act better in the future or because they were pressured to signal their commitment to international norms. As to the credible commitment theory in particular, again, one might question why an autocratic state that has declined to impose upon itself domestic accountability mechanisms would willingly impose upon itself an international accountability mechanism that could result in government leaders being tried in The Hague. On the contrary, the evidence suggests that, consistent with the credible threat theory, states with poor human rights practices and non-democracies - the very states that are likely to conclude that compliance with the ICC may be difficult and, hence, costly to their sovereignty-will be wary of joining the Court and will avoid its strong enforcement mechanisms. And, indeed, one could expect that ICC commitment would be most costly for this category of states since commitment would entail a reduction of leaders' power to rule domestically as they see fit-even if that means using violence and refusing to prosecute themselves or their compatriots who commit violent acts.

Where enforcement mechanisms are in the middle range (Enforcement Levels 3 and 4), however, results are mixed. Supportive of the credible threat theory are the findings regarding commitment to the ICCPR First Optional Protocol. As shown in Table 9, and consistent with Cole's findings,107 a state's level of human rights practices does significantly and positively predict ratification of the ICCPR First Optional Protocol. In addition, another indicator of potential compliance-namely, a state's level

107 Cole tested the influence of enforcement mechanisms on ratification decisions, but only as to the ICCPR, the ICESCR, and the ICCPR First Optional Protocol. He found that a state's level of human rights ratings did not predict ratification of the ICCPR (even as to Article 41 which allows state complaints) or of the ICESCR. However, states with better human rights ratings were more likely to join the ICCPR First Optional Protocol-a fact that Cole attributed to the differing enforcement mechanisms between the main treaties and the Optional Protocol. See Cole, supra note 21, at 485. 
of democracy-was also a significant and positive predictor of state ratification of the ICCPR First Optional Protocol. On the other hand, a state's human rights ratings did not predict ratification of the other three treaties allowing individual complaints. Instead, the only compliance cost measure that significantly predicted ratification of these three treaties was the democracy measure. But, that measure only predicted ratification of the CEDAW Optional Protocol.

Table 9: Level 3 Enforcement Mechanisms: Individual Complaints

\begin{tabular}{|l|l|l|l|l|}
\hline \multicolumn{1}{|c|}{ Explanatory Variables } & \multicolumn{4}{c|}{ Hazard Ratios } \\
\hline & $\begin{array}{l}\text { ICCPR } \\
\text { Opt. } \\
\text { Protocol }\end{array}$ & $\begin{array}{l}\text { Art. 14 } \\
\text { CERD }\end{array}$ & $\begin{array}{l}\text { Art. 22 } \\
\text { CAT }\end{array}$ & $\begin{array}{l}\text { CEDAW } \\
\text { Opt. } \\
\text { Protocol }\end{array}$ \\
\hline Level of Human Rights & $.630^{* *}$ & .813 & 1.129 & .832 \\
\hline Level of Democracy & $1.212^{* * *}$ & 1.156 & 1.137 & $1.198^{* * *}$ \\
\hline Level of Economic Development & $.622^{* * *}$ & .826 & 1.335 & .815 \\
\hline Difficulty of Ratification Process & .943 & 1.191 & .683 & 1.064 \\
\hline Common Law or Not & $.325^{* * *}$ & $.236^{* *}$ & $.217^{* * *}$ & .554 \\
\hline Transitioning Democracy or Not & 1.113 & .885 & 1.225 & .890 \\
\hline Level of Aid & .056 & 1.62 & .001 & $.007^{* *}$ \\
\hline Regional Ratifications & 1.010 & $17.867^{* *}$ & $9.400^{* *}$ & 2.828 \\
\hline \# of Countries & 102 & 131 & 129 & 138 \\
\hline \# of Ratifications & 50 & 27 & 35 & 72 \\
\hline \# of Observations & 1862 & 2766 & 1922 & 846 \\
\hline
\end{tabular}

${ }^{* *}$ significant at .05; ${ }^{* * *}$ significant at .01

In addition, as to this individual complaint enforcement mechanism, there is some limited support for the explanatory power of the normative and external pressures theories. Specifically, regional ratification rates positively and significantly influenced ratification of CERD Article 14 and CAT Article 22. However, the findings on the effect of regional ratifications are not consistent across all of the four treaties in this category. Furthermore, the other relevant normative and external pressures variable-level of aid-is not a significant predictor of ratification of any of these treaties. Thus, on the whole, the empirical evidence as to this level of enforcement mechanisms is rather inconclusive. 
On the other hand, another interpretation of these null results as to Enforcement Level 3 is that states do not view the individual complaint procedure as a very strong enforcement mechanism. If the individual complaint mechanism poses no credible threat, then states can commit without having to concern themselves with their ability to comply - meaning that the state's level of human rights ratings need not be figured into the ratification calculation. After all, the committees to whom these individual complaints are referred do not have the ability to issue legally binding decisions. Their powers are limited to persuading states to adopt their views and recommended remedies. Furthermore, there is evidence that, at least with regard to the CERD and the CEDAW, the individual complaint procedure mechanism is of little significance in practice. Jack Donnelly characterized the procedure for considering individual complaints under the CERD as "largely moribund." He noted that the CEDAW committee had only issued three decisions under the individual complaint procedure since it was empowered to consider such complaints in 2000. ${ }^{108}$

The null findings regarding the CAT Optional Protocol (Enforcement Level 4), which are reported in Table 10 below, may be explained similarly. Compliance costs may not influence ratification of the CAT Optional Protocol simply because states do not view the treaty's enforcement mechanism as a credible threat. Like the other committees, the committee overseeing that treaty is not empowered to act punitively or impose any sanctions for noncompliance. ${ }^{109}$ Furthermore, as Henry Steiner notes regarding the Human Rights Committee, it is unlikely to pose a great threat to states as it thus far is able to consider only a small number of communications, ${ }^{110}$ most of its decisions receive little publicity or

108 DONNELLY, supra note 26, at 87. Since 2005/6, when Donnelly was writing, decisions have continued to trickle out of the CEDAW Committee. The handful of Decisions and Views rendered by the Committee to date is available through the United Nations website. See Optional Protocol to the Convention on the Elimination of Discrimination against Women - Jurisprudence, OFFICE OF THE UNITED NATIONS HIGH COMM'R FOR HUMAN RIGHTS, http://www2.ohchr.org/english/law/ jurisprudence.htm (last visited Nov. 19. 2012).

109 See Steiner, supra note 31, at 37 (commenting that the ICCPR Committee's views are poor instruments to achieve greater protection of rights by all states due in part to the lack of an accompanying enforcement mechanisms).

110 A 2009 report of the Human Rights Committee indicated that it had issued forty-six decisions (and declared twenty-nine cases inadmissible) between October 2008 and July 2009. See Rep. of the Human Rights Comm. Vol. I, 94th sess, Oct. 13-31, 2008, 95th sess, Mar. 16-Apr. 3, 2009, 96th sess, July 13-31, 2009, iii, U.N. Doc. A/64/40; GAOR, 64th Sess., Supp. No. 40 (2009). 
attention, and the suggested remedies - compensation, release of a prisoner, or changes to legislation-do not likely threaten state interests sufficiently. ${ }^{111}$ Those same issues presumably prevail in connection with committees for each of the main international human rights treaties and affect how states view the enforcement mechanisms associated with treaty ratification.

Table 10: Level 4 Enforcement Mechanism: Committee Visits

\begin{tabular}{|l|l|}
\hline \multicolumn{1}{|c|}{ Explanatory Variables } & \multicolumn{1}{c|}{ Hazard Ratios } \\
\hline & CAT Optional Protocol \\
\hline Level of Human Rights & .732 \\
\hline Level of Democracy & 1.215 \\
\hline Level of Economic Development & .691 \\
\hline Difficulty of Ratification Process & .832 \\
\hline Common Law or Not & 1.71 \\
\hline Transitioning Democracy or Not & 1.443 \\
\hline Level of Aid & .008 \\
\hline Regional Ratifications & 7.349 \\
\hline \# of Countries & 135 \\
\hline \# of Ratifications & 30 \\
\hline \# of Observations & 600 \\
\hline ** significant at .05; ***significant at .01
\end{tabular}

\section{CONCLUSION}

The quantitative analysis in this study of the relationship between treaty enforcement mechanisms and the likelihood of ratification across a broad range of international human rights treaties provides evidence that state behavior is influenced by compliance costs - but only where enforcement mechanisms are strong enough to hold states to their commitments. The statistical analyses offer evidence that states view international human rights treaties with stronger enforcement mechanisms as a credible threat. I find that states with poor human rights records regularly commit to international human rights treaties with the weakest enforcement mechanisms. On the other hand, states with poorer records are less likely to commit to the ICC. The implication is that where enforcement mechanisms are stronger, states take their commitment to international human rights treaties seriously.

111 Steiner, supra note 31, at 36-37. 
Thus, it may be that states are committing to treaties with weak enforcement mechanisms in an effort to signal their legitimacy, without any real intention of bettering their human rights practices. At least some of those states may conclude that the costs of commitment are cheap and the consequences of noncompliance are meager or nonexistent. States may commit to the ICC for other reasons entirely - because they intend to comply with treaty terms. After all, should they fail to comply, states face a substantial risk to their sovereignty - state leaders or citizens can be hauled to The Hague to stand trial.

The results further indicate that for enforcement mechanisms to pose a credible threat, they must include a formal grant of power to engage in legally binding decision-making accompanied by resources to coerce compliance. The empirical tests indicate that states do not view any of the enforcement mechanisms in Levels 1 through 4 as a credible threat. In none of those cases is a state's level of human rights ratings a consistent, significant, and positive predictor of ratification, suggesting that states are not overly concerned with compliance costs where enforcement mechanisms do not include a grant of power to engage in legally binding decision-making. Only in the case of the ICC treatyis a state's level of human rights practices a significant and positive predictor of ratification. Only that treaty contains an enforcement mechanism that allows for legally binding decision-making. States joining the ICC treaty delegate to an independent Prosecutor and to the Court the powers to mount investigations, issue arrest warrants, commence investigations, and punish persons who commit mass atrocities where the state refuses or is unable to do so domestically. The evidence suggests that in the case of ICC commitment, states are concerned about the costs of the compliance and the relative strength of the ICC treaty's enforcement mechanisms and engage in backward-looking calculations about their likelihood of compliance prior to commitment.

I thus argue that another implication of these statistical analyses is that treaties with stronger enforcement mechanisms have the best chance of actually influencing and changing states' human rights behavior for the better. Even if fewer states ratify, designing treaties so that states focus on the potential for compliance with treaty terms makes sense since the point of international human rights treaties is to actually promote better human rights practices and punish those who abuse human rights. If states are committing to international human rights treaties 
without regard for their ability to comply - something which this and other studies 112 have shown to occur when enforcement mechanisms are weak - the prospects for realizing treaty goals are slim. A brief look at some of the states listed in Table 5 may help illustrate this point. For example, Egypt, Ethiopia, Indonesia, Israel, Lebanon, Libya, Morocco, Russia, Syria, and Turkey are members of the six main international human rights treaties-some for decades. Yet, these states all continue to have relatively poor human rights ratings. My review of the data shows that the 2008 political terror scale rating for all of these states is generally well below average (on a scale ranging from 1 to 5, with 5 being the worst practices). ${ }^{113}$ This alone provides some proof that allowing states-or even encouraging them-to commit to international human rights treaties with weak enforcement mechanisms incapable of punishing the bad and noncompliant may not be sufficient to produce positive change. In fact, some states with bad records may be using the fact that they ratified these treaties as something of a shield for their bad behavior: they can point to their membership in an effort to avoid scrutiny of their actual domestic practices. ${ }^{114}$

This study has looked at the role treaty terms can play in states' ex ante beliefs about the institution and the role that the existence of apparently stronger enforcement mechanisms can play in screening states at the ratification stage. Future research should look at the actual impact of those stronger enforcement mechanisms and the role they play in improving compliance with treaty terms. For example, with the ICC treaty and its stronger enforcement mechanism, researchers can look for evidence that states have changed their laws to provide for the punishment of those who commit mass atrocities; evidence that states have improved their military training and practices so that they do not

112 See Wotipka \& Tsutsui, supra note 22, at 744-47 (noting that results of event history analyses concerning state ratification of seven international human rights treaties - all of which contained only reporting enforcement mechanisms showed that "rights-violating governments are more likely to ratify human rights treaties in a given year, all else being equal.").

113 The ratings for 2008 are as follows: Egypt (3.5); Ethiopia (3.5); Indonesia (3.5); Israel (5); Lebanon (3); Libya (3); Morocco (3); Russia (4); Syria (4); and Turkey (3.5).

114 See Hafner-Burton \& Tsutsui, supra note 5, at 1374 (observing that while the average state ratified an increasing percentage of available human rights treaties, the percentage of states reported to repress human rights has likewise increased). 
run afoul of the treaty's war crimes provisions; and evidence that states are domestically prosecuting crimes otherwise within the ICC's jurisdiction so as to avoid any loss of sovereignty.

Future research should also look beyond treaty terms and examine how the actual functioning of the institutions responsible for monitoring and/or enforcing compliance with the terms and goals of international human rights treaties influences state commitment and compliance. If the institutions in charge of enforcing compliance are weak or ineffective, we may see that even where enforcement mechanisms are strong on paper, states will view the actual enforcement mechanisms as weak and commit without an intention to comply with treaty terms. On the other hand, if institutions are effective and if states see that the institution is effectively punishing noncompliant behavior, states should have even more reason to view strong enforcement mechanisms as a credible threat and behave accordingly. Indeed, if future research does show that states respond to the credible threat of strong enforcement mechanisms and alter their behavior so as to comply with those enforcement mechanisms, at least some international human rights treaties may actually realize their goals of improving human rights practices and ensuring that those who do abuse individual human rights are punished. 


\section{APPENDIX A}

\section{States Parties to the 14 Different Treaties, Articles, and/or Protocols}

ICCPR (166 State Parties): Afghanistan, Albania, Algeria, Andorra, Angola, Argentina, Armenia, Australia, Austria, Azerbaijan, Bahamas, Bahrain, Bangladesh, Barbados, Belarus, Belgium, Belize, Benin, Bolivia, Bosnia and Herzegovina, Botswana, Brazil, Bulgaria, Burkina Faso, Burundi, Cambodia, Cameroon, Canada, Cape Verde, Central African Republic, Chad, Chile, Colombia, Congo, Costa Rica, Cote d'Ivoire, Croatia, Cyprus, Czech Republic, North Korea, Democratic Republic of Congo, Denmark, Djibouti, Dominica, Dominican Republic, Ecuador, Egypt, El Salvador, Equatorial Guinea, Eritrea, Estonia, Ethiopia, Finland, France, Gabon, Gambia, Georgia, Germany, Ghana, Greece, Grenada, Guatemala, Guinea, Guyana, Haiti, Honduras, Hungary, Iceland, India, Indonesia, Iran, Iraq, Ireland, Israel, Italy, Jamaica, Japan, Jordan, Kazakhstan, Kenya, Kuwait, Kyrgyzstan, Latvia, Lebanon, Lesotho, Liberia, Libya, Liechtenstein, Lithuania, Luxembourg, Madagascar, Malawi, Maldives, Mali, Malta, Mauritania, Mauritius, Mexico, Monaco, Mongolia, Montenegro, Morocco, Mozambique, Namibia, Nepal, Netherlands, New Zealand, Nicaragua, Niger, Nigeria, Norway, Panama, Papua New Guinea, Paraguay, Peru, Philippines, Poland, Portugal, South Korea, Moldova, Romania, Russia, Rwanda, Samoa, San Marino, Saudi Arabia, Senegal, Serbia, Seychelles, Sierra Leone, Singapore, Slovakia, Slovenia, Somalia, South Africa, Spain, Sri Lanka, St. Vincent and the Grenadines, Sudan, Suriname, Swaziland, Sweden, Switzerland, Syria, Tajikistan, Thailand, Macedonia, Timor-Leste, Togo, Trinidad and Tobago, Tunisia, Turkey, Turkmenistan, Uganda, Ukraine, United Kingdom, Tanzania, United States, Uruguay, Uzbekistan, Vanuatu, Venezuela, Vietnam, Yemen, Zambia, Zimbabwe.

Article 41 (48 State Parties): Algeria, Argentina, Australia, Austria, Belarus, Belgium, Bosnia and Herzegovina, Bulgaria, Canada, Chile, Congo, Croatia, Czech Republic, Denmark, Ecuador, Finland, Gambia, Germany, Ghana, Guyana, Hungary, Iceland, Ireland, Italy, Liechtenstein, Luxembourg, Malta, Netherlands, New Zealand, Norway, Peru, Philippines, Poland, South Korea, Russia, Senegal, Slovakia, Slovenia, South Africa, Spain, Sri Lanka, Sweden, Switzerland, Tunisia, Ukraine, United Kingdom, United States, Zimbabwe. 
Optional Protocol (115 State Parties): Albania, Algeria, Andorra, Angola, Argentina, Armenia, Australia, Austria, Azerbaijan, Barbados, Belarus, Belgium, Benin, Bolivia, Bosnia and Herzegovina, Bulgaria, Burkina Faso, Cameroon, Canada, Cape Verde, Central African Republic, Chad, Chile, Colombia, Congo, Costa Rica, Cote d'Ivoire, Croatia, Cyprus, Czech Republic, Democratic Republic of Congo, Denmark, Djibouti, Dominican Republic, Ecuador, El Salvador, Equatorial Guinea, Estonia, Finland, France, Gabon, Gambia, Georgia, Germany, Ghana, Greece, Guatemala, Guinea, Guyana, Honduras, Hungary, Iceland, Ireland, Italy, Jamaica, Kazakhstan, Kyrgyzstan, Latvia, Lesotho, Libya, Liechtenstein, Lithuania, Luxembourg, Madagascar, Malawi, Maldives, Mali, Malta, Mauritius, Mexico, Mongolia, Montenegro, Namibia, Nepal, Netherlands, New Zealand, Nicaragua, Niger, Norway, Panama, Paraguay, Peru, Philippines, Poland, Portugal, South Korea, Moldova, Romania, Russia, San Marino, Senegal, Serbia, Seychelles, Sierra Leone, Slovakia, Slovenia, Somalia, South Africa, Spain, Sri Lanka, St. Vincent and the Grenadines, Suriname, Sweden, Tajikistan, Macedonia, Togo, Trinidad and Tobago (denounced 2000), Turkey, Turkmenistan, Uganda, Ukraine, Uruguay, Uzbekistan, Venezuela, Zambia.

ICESCR (160 State Parties): Afghanistan, Albania, Algeria, Angola, Argentina, Armenia, Australia, Austria, Azerbaijan, Bahamas, Bahrain, Bangladesh, Barbados, Belarus, Belgium, Benin, Bolivia, Bosnia, Brazil, Bulgaria, Burkina Faso, Burundi, Cambodia, Cameroon, Canada, Cape Verde, Central African Republic, Chad, Chile, China, Colombia, Costa Rica, Croatia, Cyprus, Czech Republic, Democratic Republic of Congo, Denmark, Djibouti, Dominica, Dominican Republic, East Timor, Ecuador, Egypt, El Salvador, Equatorial Guinea, Eritrea, Estonia, Ethiopia, Finland, France, Gabon, Gambia, Georgia, Germany, Ghana, Greece, Grenada, Guatemala, Guinea, Guinea-Bissau, Guyana, Honduras, Hungary, Iceland, India, Indonesia, Iran, Iraq, Ireland, Israel, Italy, Ivory Coast, Jamaica, Japan, Jordan, Kazakhstan, Kenya, Kyrgyzstan, Kuwait, Laos, Latvia, Lebanon, Lesotho, Liberia, Libya, Liechtenstein, Lithuania, Luxembourg, Macedonia, Madagascar, Malawi, Maldives, Mali, Malta, Mauritania, Mauritius, Mexico, Moldova, Monaco, Mongolia, Montenegro, Morocco, Namibia, Nepal, Netherlands, New Zealand, Nicaragua, Niger, Nigeria, North Korea, Norway, Pakistan, Panama, Papua New Guinea, Paraguay, Peru, Philippines, Poland, Portugal, Republic of Congo, Romania, Russia, Rwanda, San Marino, Senegal, Serbia, Seychelles, Sierra Leone, Slovak Republic, Slovenia, Solomon Islands, Somalia, South Korea, Spain, Sri Lanka, St. Vincent and the 
Grenadines, Sudan, Suriname, Swaziland, Sweden, Switzerland, Syria, Tajikistan, Tanzania, Thailand, Togo, Trinidad and Tobago, Tunisia, Turkey, Turkmenistan, Uganda, Ukraine, United Kingdom, Uruguay, Uzbekistan, Venezuela, Vietnam, Yemen, Zambia, Zimbabwe.

CERD (173 State Parties): Afghanistan, Albania, Algeria, Andorra, Antigua, Argentina, Armenia, Australia, Austria, Azerbaijan, Bahamas, Bahrain, Bangladesh, Barbados, Belarus, Belgium, Belize, Benin, Bolivia, Bosnia, Botswana, Brazil, Bulgaria, Burkina Faso, Burundi, Cambodia, Cameroon, Canada, Cape Verde, Central African Republic, Chad, Chile, China, Colombia, Comoros, Costa Rica, Croatia, Cuba, Cyprus, Czech Republic, Democratic Republic of Congo, Denmark, Dominican Republic, East Timor, Ecuador, Egypt, El Salvador, Equatorial Guinea, Eritrea, Estonia, Ethiopia, Fiji, Finland, France, Gabon, Gambia, Georgia, Germany, Ghana, Greece, Guatemala, Guinea, Guyana, Haiti, Honduras, Hungary, Iceland, India, Indonesia, Iran, Iraq , Ireland, Israel, Italy, Ivory Coast, Jamaica, Japan, Jordan, Kazakhstan, Kenya, Kyrgyzstan, Kuwait, Laos, Latvia, Lebanon, Lesotho, Liberia, Libya, Liechtenstein, Lithuania, Luxembourg, Macedonia, Madagascar, Malawi, Maldives, Mali, Malta, Mauritania, Mauritius, Mexico, Moldova, Monaco, Mongolia, Montenegro, Morocco, Mozambique, Namibia, Nepal, Netherlands, New Zealand, Nicaragua, Niger, Nigeria, Norway, Oman, Pakistan, Panama, Papua New Guinea, Paraguay, Peru, Philippines, Poland, Portugal, Qatar, Republic of Congo, Romania, Russia, Rwanda, San Marino, Saudi Arabia, Senegal, Serbia, Seychelles, Sierra Leone, Slovak Republic, Slovenia, Solomon Islands, Somalia, South Africa, South Korea, Spain, Sri Lanka, St. Kitts and Nevis, St. Lucia, St. Vincent and the Grenadines, Sudan, Suriname, Swaziland, Sweden, Switzerland, Syria, Tajikistan, Tanzania, Thailand, Togo, Tonga, Trinidad and Tobago, Tunisia, Turkey, Turkmenistan, Uganda, Ukraine, United Arab Emirates, United Kingdom, United States, Uruguay, Uzbekistan, Venezuela, Vietnam, Yemen, Zambia, Zimbabwe.

Article 14 (53 State Parties): Algeria, Andorra, Argentina, Australia, Austria, Azerbaijan, Belgium, Bolivia, Brazil, Bulgaria, Chile, Costa Rica, Cyprus, Czech Republic, Denmark, Ecuador, Finland, France, Georgia, Germany, Hungary, Iceland, Ireland, Italy, Kazakhstan, Liechtenstein, Luxembourg, Macedonia, Malta, Mexico, Monaco, Montenegro, Morocco, Netherlands, Norway, Peru, Poland, Portugal, Romania, Russia, San Marino, Senegal, Serbia, Slovak Republic, Slovenia, South Africa, South Korea, Spain, Sweden, Switzerland, Ukraine, Uruguay, Venezuela. 
CEDAW (185 State Parties): Afghanistan, Albania, Algeria, Andorra, Angola, Antigua and Barbuda, Argentina, Armenia, Australia, Austria, Azerbaijan, Bahamas, Bahrain, Bangladesh, Barbados, Belarus, Belgium, Belize, Benin, Bhutan, Bolivia, Bosnia and Herzegovina, Botswana, Brazil, Brunei, Bulgaria, Burkina Faso, Burundi, Cambodia, Cameroon, Canada, Cape Verde, Central African Republic, Chad, Chile, China, Colombia, Comoros, Congo, Cook Islands, Costa Rica, Cote d'Ivoire, Croatia, Cuba, Cyprus, Czech Republic, North Korea, Democratic Republic of Congo, Denmark, Djibouti, Dominica, Dominican Republic, Ecuador, Egypt, El Salvador, Equatorial Guinea, Eritrea, Estonia, Ethiopia, Fiji, Finland, France, Gabon, Gambia, Georgia, Germany, Ghana, Greece, Grenada, Guatemala, Guinea, Guinea-Bissau, Guyana, Haiti, Honduras, Hungary, Iceland, India, Indonesia, Iraq, Ireland, Israel, Italy, Jamaica, Japan, Jordan, Kazakhstan, Kenya, Kiribati, Kuwait, Kyrgyzstan, Laos, Latvia, Lebanon, Lesotho, Liberia, Libya, Liechtenstein, Lithuania, Luxembourg, Madagascar, Malawi, Malaysia, Maldives, Mali, Malta, Marshall Islands, Mauritania, Mauritius, Mexico, Micronesia, Monaco, Mongolia, Montenegro, Morocco, Mozambique, Myanmar, Namibia, Nepal, Netherlands, New Zealand, Nicaragua, Niger, Nigeria, Norway, Oman, Pakistan, Panama, Papua New Guinea, Paraguay, Peru, Philippines, Poland, Portugal, Qatar, South Korea, Moldova, Romania, Russia, Rwanda, Samoa, San Marino, Sao Tome and Principe, Saudi Arabia, Senegal, Serbia, Seychelles, Sierra Leone, Singapore, Slovakia, Slovenia, Solomon Islands, South Africa, Spain, Sri Lanka, St. Kitts and Nevis, St. Lucia, St. Vincent and the Grenadines, Suriname, Swaziland, Sweden, Switzerland, Syria, Tajikistan, Thailand, Macedonia, Timor-Leste, Togo, Trinidad and Tobago, Tunisia, Turkey, Turkmenistan, Tuvalu, Uganda, Ukraine, United Arab Emirates, United Kingdom, Tanzania, Uruguay, Uzbekistan, Vanuatu, Venezuela, Vietnam, Yemen, Zimbabwe.

Optional Protocol (98 State Parties): Albania, Andorra, Angola, Antigua and Barbuda, Argentina, Armenia, Australia, Austria, Azerbaijan, Bangladesh, Belarus, Belgium, Belize, Bolivia, Bosnia and Herzegovina, Botswana, Brazil, Bulgaria, Burkina Faso, Cameroon, Canada, Colombia, Cook Islands, Costa Rica, Croatia, Cyprus, Czech Republic, Denmark, Dominican Republic, Ecuador, Equatorial Guinea, Finland, France, Gabon, Georgia, Germany, Greece, Guatemala, Guinea-Bissau, Hungary, Iceland, Ireland, Kazakhstan, Krygyzstan, Lesotho, Libya, Liechtenstein, Lithuania, Luxembourg, Maldives, Mali, Mauritius, Mexico, Mongolia, Montenegro, Mozambique, Namibia, Nepal, Netherlands, New Zealand, Niger, Nigeria, Norway, Panama, Paraguay, Peru, Philippines, Poland, Portugal, South Korea, Moldova, Romania, Russia, Rwanda, San Marino, Senegal, Serbia, Slovakia, Slovenia, Solomon Islands, South Africa, Spain, 
Sri Lanka, St. Kitts and Nevis, Sweden, Switzerland, Thailand, Macedonia, Timor-Leste, Tunisia, Turkey, Turkmenistan, Ukraine, United Kingdom, Tanzania, Uruguay, Vanuatu, Venezuela.

CAT (147 State Parties): Afghanistan, Albania, Algeria, Andorra, Antigua and Barbuda, Argentina, Armenia, Australia, Austria, Azerbaijan, Bahrain, Bangladesh, Belarus, Belgium, Belize, Benin, Bolivia, Bosnia and Herzegovina, Botswana, Brazil, Bulgaria, Burkina Faso, Burundi, Cambodia, Cameroon, Canada, Cape Verde, Chad, Chile, China, Colombia, Comoros, Congo, Costa Rica, Cote d'Ivoire, Croatia, Cuba, Cyprus, Czech Republic, Democratic Republic of the Congo, Denmark, Djibouti, Ecuador, Egypt, El Salvador, Equatorial Guinea, Estonia, Ethiopia, Finland, France, Gabon, Georgia, Germany, Ghana, Greece, Guatemala, Guinea, Guyana, Holy See, Honduras, Hungary, Iceland, Indonesia, Ireland, Israel, Italy, Japan, Jordan, Kazakhstan, Kenya, Kuwait, Kyrgyzstan, Latvia, Lebanon, Lesotho, Liberia, Libya, Liechtenstein, Lithuania, Luxembourg, Madagascar, Malawi, Maldives, Mali, Malta, Mauritania, Mauritius, Mexico, Monaco, Mongolia, Montenegro, Morocco, Mozambique, Namibia, Nepal, Netherlands, New Zealand, Nicaragua, Niger, Nigeria, Norway, Panama, Paraguay, Peru, Philippines, Poland, Portugal, Qatar, South Korea, Moldova, Romania, Russia, Rwanda, San Marino, Saudi Arabia, Senegal, Serbia, Seychelles, Sierra Leone, Slovakia, Slovenia, Somalia, South Africa, Spain, Sri Lanka, St. Vincent and the Grenadines, Swaziland, Sweden, Switzerland, Syria, Tajikistan, Thailand, Macedonia, Timor-Leste, Togo, Tunisia, Turkey, Turkmenistan, Uganda, Ukraine, United Kingdom, United States, Uruguay, Uzbekistan, Venezuela, Yemen, Zambia.

Article 21 (60 State Parties): Algeria, Andorra, Argentina, Australia, Austria, Belgium, Bolivia, Bulgaria, Cameroon, Canada, Chile, Costa Rica, Croatia, Cyprus, Czech Republic, Denmark, Ecuador, Finland, France, Georgia, Germany, Ghana, Greece, Hungary, Iceland, Ireland, Italy, Japan, Kazakhstan, Liechtenstein, Luxembourg, Malta, Monaco, Montenegro, Netherlands, New Zealand, Norway, Paraguay, Peru, Poland, Portugal, South Korea, Russia, Senegal, Serbia, Slovakia, Slovenia, South Africa, Spain, Sweden, Switzerland, Togo, Tunisia, Turkey, Uganda, Ukraine, United Kingdom, United States, Uruguay, Venezuela. 
Article 22 (64 State Parties): Algeria, Andorra, Argentina, Australia, Austria, Azerbaijan, Belgium, Bolivia, Bosnia and Herzegovina, Brazil, Bulgaria, Burundi, Cameroon, Canada, Chile, Costa Rica, Croatia, Cyprus, Czech Republic, Denmark, Ecuador, Finland, France, Georgia, Germany, Ghana, Greece, Guatemala, Hungary, Iceland, Ireland, Italy, Kazakhstan, Liechtenstein, Luxembourg, Malta, Mexico, Monaco, Montenegro, Morocco, Netherlands, New Zealand, Norway, Paraguay, Peru, Poland, Portugal, South Korea, Russia, Senegal, Serbia, Seychelles, Slovakia, Slovenia, South Africa, Spain, Sweden, Switzerland, Togo, Tunisia, Turkey, Ukraine, Uruguay, Venezuela.

Optional Protocol (48 State Parties): Albania, Argentina, Armenia, Azerbaijan, Benin, Bolivia, Bosnia and Herzegovina, Brazil, Cambodia, Chile, Costa Rica, Croatia, Cyprus, Czech Republic, Denmark, Estonia, France, Georgia, Germany, Guatemala, Honduras, Kazakhstan, Kyrgyzstan, Lebanon, Liberia, Maldives, Mali, Malta, Mauritius, Mexico, Montenegro, New Zealand, Nicaragua, Nigeria, Paraguay, Peru, Poland, Moldova, Romania, Senegal, Serbia, Slovenia, Spain, Sweden, Macedonia, Ukraine, United Kingdom, Uruguay.

CRC (193 State Parties): Afghanistan, Albania, Algeria, Andorra, Angola, Antigua, Argentina, Armenia, Australia, Austria, Azerbaijan, Bahamas, Bahrain, Bangladesh, Barbados, Belarus, Belgium, Belize, Benin, Bhutan, Bolivia, Bosnia, Botswana, Brazil, Brunei, Bulgaria, Burkina Faso, Burundi, Cambodia, Cameroon, Canada, Cape Verde, Central African Republic, Chad, Chile, China, Colombia, Comoros, Cook Islands, Costa Rica, Croatia, Cuba, Cyprus, Czech Republic, Democratic Republic of Congo, Denmark, Djibouti, Dominica, Dominican Republic, East Timor, Ecuador, Egypt, El Salvador, Equatorial Guinea, Eritrea, Estonia, Ethiopia, Fiji, Finland, France, Gabon, Gambia, Georgia, Germany, Ghana, Greece, Grenada, Guatemala, Guinea, Guinea-Bissau, Guyana, Haiti, Honduras, Hungary, Iceland, India, Indonesia, Iran, Iraq, Ireland , Israel, Italy, Ivory Coast, Jamaica, Japan , Jordan, Kazakhstan, Kenya, Kiribati, Kyrgyzstan, Kuwait, Laos, Latvia, Lebanon, Lesotho, Liberia, Libya, Liechtenstein, Lithuania, Luxembourg, Macedonia, Madagascar, Malawi, Maldives, Mali, Malta, Marshall Islands, Mauritania, Mauritius, Mexico, Micronesia, Moldova, Monaco, Mongolia, Montenegro, Morocco, Mozambique, Myanmar, Namibia, Nauru, Nepal, Netherlands, New Zealand, Nicaragua, Niger, Nigeria, North Korea, Norway, Oman, Pakistan, Palau, Panama, Papua New Guinea, Paraguay, Peru, Philippines, Poland, Portugal, Qatar, Republic of Congo, Romania, Russia, Rwanda, Samoa, San Marino, Sao Tome and Principe, Saudi 
Arabia, Senegal, Serbia, Serbia, Seychelles, Sierra Leone, Singapore, Slovak Republic, Slovenia, Slovenia, Solomon Islands, South Africa, South Korea, Spain, Sri Lanka, St. Kitts and Nevis, St. Lucia, St. Vincent and the Grenadines, Sudan, Suriname, Swaziland, Sweden, Switzerland, Syria, Tajikistan, Tanzania, Thailand, Togo, Tonga, Trinidad and Tobago, Tunisia, Turkey, Turkmenistan, Tuvalu, Uganda, Ukraine, United Arab Emirates, United Kingdom, Uruguay, Uzbekistan, Vanuatu, Venezuela, Vietnam, Yemen, Zambia, Zimbabwe.

ICC (111 State Parties): Afghanistan, Albania, Andorra, Antigua and Barbuda, Argentina, Australia, Austria, Bangladesh, Barbados, Belgium, Belize, Benin, Bolivia, Bosnia and Herzegovina, Botswana, Brazil, Bulgaria, Burkina Faso, Burundi, Cambodia, Canada, Central African Republic, Chad, Chile, Colombia, Comoros, Congo, Cook Islands, Costa Rica, Croatia, Cyprus, Czech Republic, Democratic Republic of Congo, Denmark, Djibouti, Dominica, Dominican Republic, East Timor, Ecuador, Estonia, Fiji, Finland, France, Gabon, Gambia, Georgia, Germany, Ghana, Greece, Guinea, Guyana, Honduras, Hungary, Iceland, Ireland, Italy, Japan, Jordan, Kenya, Latvia, Lesotho, Liberia, Liechtenstein, Lithuania, Luxembourg, Macedonia, Madagascar, Malawi, Mali, Malta, Marshall Islands, Mauritius, Mexico, Mongolia, Montenegro, Namibia, Nauru, Netherlands, New Zealand, Niger, Nigeria, Norway, Panama, Paraguay, Peru, Poland, Portugal, South Korea, Romania, St. Kitts \& Nevis, St. Vincent \& the Grenadines, Samoa, San Marino, Senegal, Serbia, Sierra Leone, Slovakia, Slovenia, South Africa, Spain, Suriname, Sweden, Switzerland, Tajikistan, Tanzania, Trinidad and Tobago, Uganda, United Kingdom, Uruguay, Venezuela, Zambia. 


\section{APPENDIX B}

\section{CONTROL VARIABLES DATA DESCRIPTION}

Democracy: The democracy indicator is a time-varying measure coded on a 0 to 10 scale, with scores based on several dimensions of democracy: (1) competitiveness of political participation; (2) openness and competitiveness of executive recruitment; and (3) constraints on the chief executive. See Monty G. Marshall, Ted Robert Gurr \& Keith Jaggers, Polity IV Project: Political Regime Characteristics and Transitions, 1800-2009, CTR. FOR SYSTEMIC PEACE (Apr. 30, 2010), available at http:// www.systemicpeace.org/inscr/p4manualv2009.pdf.

GDP Per Capita: I obtain the GDP per capita measure for the "level of economic development" variable from the World Bank World Development Indicators dataset. I also log the measure to reduce a skewed distribution. This measure indicates the level of a state's wealth and is correlated with its level of industrialization. This is a time-varying measure that is reported in constant U.S. dollars. See Data: United States, THE WORLD BANK, http://data.worldbank.org/country/united-states (last visited Oct. 9, 2012).

Difficulty of Domestic Treaty Ratification Process: The Simmons data used to measure this concept of codes describes ratification processes using a four-category scale designed to capture the level of difficulty in the formal domestic ratification process. The categories are as follows: (1) treaties may be ratified by an individual chief executive or cabinet; (1.5) there is a rule or tradition of informing the legislature of signed treaties; (2) treaties may only be ratified upon consent of one legislative body; (3) treaties may only be ratified by a supermajority vote in one legislative body or by a majority vote in two separate legislative bodies; (4) treaties may be ratified through national plebiscite. The source and detailed description of this data are available on Simmons' website. See BETH A. SIMMONS, MOBILIZING FOR HUMAN RIGHTS: INTERNATIONAL LAW IN DOMESTIC POLITICS app. 3.2 (2009), available at http://scholar.harvard.edu/bsimmons/files/APP_ 3.2_Ratification_rules.pdf. 
Common Law State or Not: I measure whether a state follows a common law tradition or not using a dichotomous variable. I obtained the data for this variable from the Global Network Growth Database created by William Easterly. See William R. Easterly, Global Development Network Growth Database, THE WORLD BANK (June 1, 2001), http:// econ.worldbank.org/WBSITE/ EXTERNAL/EXTDEC/EXTRESEARCH/0,,contentMDK:20701055 pagePK:64214825 piPK:64214943 theSitePK:469382,00.html\#4.

Transitioning Democracy or Not: I use a dichotomous variable to measure whether a state is a newly transitioning democracy or not based on the Polity IV democracy variable. Following Simmons, who used 7 as the number above which she considered countries to have transitioned to "democracy" in her work testing state commitment to and compliance with various international human rights treaties, I code states as a 1 and as new democracies in a given year if they transitioned from anywhere below a 7 on the Polity IV scale to a 7 or above. See SIMMONS, supra note 22, at 385. If states were consistently above 7 for the Post-World War II period, I consider them to be stable democracies and code them 0 . If states are consistently below a $7, \mathrm{I}$ consider them nondemocracies and also code them 0 .

Official Development Assistance: I obtain the time-varying ODA data to measure the idea that states may be pressured to join international human rights treaties so as to obtain extra-treaty benefits like aid from the World Bank World Development Indicators. The data are reported in constant 2007 U.S. dollars as a share of GDP. See Data: United States, THE WORLD BANK, http://data.worldbank.org/country/united-states (last visited Oct. 9, 2012). 